\title{
GEOCHEMISTRY AND ENVIRONMENTAL ASSESSMENT OF HEAVY METALS IN SURFACE SOIL IN AL-HAWIJA, SOUTHWEST KIRKUK
}

\author{
${ }^{1}$ Ahmed H. Al-Obeidi" and ${ }^{\mathbf{1}}$ Hassan A. A. Al-Jumaily \\ ${ }^{1}$ Department of Applied Geology, College of Science, University of Kirkuk, Kirkuk, Iraq \\ "E-mail: ahmed.h.alobeidi@gmail.com \\ Received: 1 July 2020; accepted: 21 September 2020
}

\begin{abstract}
Soil pollution adversely affects the safety and health of the human being. The main objective of the study is to determine the concentrations of heavy metals ( $\mathrm{As}, \mathrm{Cd}, \mathrm{Co}, \mathrm{Cr}, \mathrm{Cu}, \mathrm{Fe}, \mathrm{Mn}$, $\mathrm{Mo}, \mathrm{Ni}, \mathrm{Pb}$ and $\mathrm{Zn}$ ) in surface soil in Al-Hawija, southwestern Kirkuk. Twenty-one samples were collected and analyzed by inductively coupled plasma-mass spectrometry (ICP-MS) to measure the content of heavy metals and assess the soil pollution by using the contamination factor, degree of contamination, geoaccumulation index, pollution load index and ecological risk index (RI). The results indicate that there is high pollution by lead, chromium and copper $(78.8,87.4$ and $53.8 \mathrm{mg} / \mathrm{kg}$ ) respectively, in industrial areas due to anthropogenic sources with the presence of significant ecological risk (Er) of the lead (116) in site S7, due to its high concentrations, while size fraction analysis indicated that all heavy metals are concentrated in the fine parts as a result of adsorption processes by clay minerals.
\end{abstract}

Keywords: Heavy metals; Pollution; Statistical analysis; Size fraction

\section{INTRODUCTION}

Environmental pollution with heavy metals is defined as a background increase in the surface sediments of urban areas caused by anthropogenic activities (Hanfi et al., 2019). Heavy metals are defined as metals with a density greater than $7 \mathrm{~g} / \mathrm{cm} 3$ (Bjerrum, 1936). Ali and Khan (2018) suggested a more comprehensive definition of the "heavy metals as the element that occurs naturally and has atomic number is greater than 20 and the density is greater than $5 \mathrm{~g}$ $/ \mathrm{cm}^{3}$ ". Thousands papers have been published in international journals on various aspects of heavy metals pollution, "heavy metals" has been used in general for elements and metals related to environmental pollution, toxic effects and health risk to organisms and people (Ali and Khan, 2018), because of its ability to accumulate in the human body and causing damage to some of its organs (Lee et al., 2007; Lohani et al., 2008). Soil pollution poses a major threat to 
environmental sustainability (Su, 2014), and affects the well-being and economy of society (Jónsson et al., 2016), According to World Health Organization, air, water and soil pollution, chemical materials exposure, climate change, and ultraviolet rays may contribute to more than 100 diseases, as human health is associated with the surrounding environment (WHO, 2016). Soil is one of the most important basic units for all terrestrial ecosystems, as it provides a chemical and biological link in biogeochemical cycles (Pietrzykowski et al., 2014). In addition to the main elements such as $\mathrm{C}, \mathrm{P}, \mathrm{N}, \mathrm{Ca}, \mathrm{Mg}$ and $\mathrm{S}$, heavy metals also participate in biogeochemical cycles that have toxic effects (Kabata-Pendias and Mukherjee, 2007), and the heavy metals accumulation is affected by environmental variables in the soil, which include source rocks and soil properties (Albanese et al., 2015) mobility and availability depend on the origin of heavy metals, as the metals with lithogenic origin are low in motion due to their dominantly linked with the primary minerals, by contrast, the heavy metals anthropogenic sources that are mostly highly mobile (Kabata-Pendias, 1993). The mobility, activity, and availability of the element also depend on the specifications of that element and the chemical and mineral soil properties such as organic material, clay percent, and pH (Di Giuseppe et al., 2014; Othman et al., 2020). The size fraction affects its distribution in the soil as the clay have high adsorption to these metals due to its possession of large surface area (Sherene, 2010). The Natural sources of heavy metals are geological weathering and erosion of soil, and airborne dust, (Men et al., 2018), under certain geological conditions, releases of heavy metals may occur from volcanic eruptions in the form of gases or lava or from the sea-salt sprays and wind-borne soil particles, fires forests are also natural sources (Masindi and Muedi, 2018)but the anthropogenic sources are mining and disposal of untreated or partially treated liquid pollutants and various industries such as pharmaceutical and excessive use of fertilizers and pesticides containing concentrations of heavy metals (Karbassi and Amirnezhad, 2004; Al-Jaberi et al., 2016). The aims of this research are to study the geochemistry and environmental pollution assessment of heavy metals in surface soil that resulting from anthropogenic activities in AlHawija area.

\section{MATERIALS AND METHODS}

\section{Study Area}

Al-Hawija is located between the longitude (43.755 - 43.79 E) and latitude (35.43-35.315 N) away $65 \mathrm{~km}$ from Kirkuk to the southwest (Fig. 1), with a population of 118215 people (Ministry of Municipalities and Public Works, 2014). Tectonically, the town falls within the range of low folded zone in the Hemrin-Makhul subzone (Jassim and Goff, 2006). Stratigraphically, covered with quaternary deposits consisting of river deposits forming 
floodplains and there is no formation exposed on the surface (Buringh, 1960). The soil of this region in general is silty formed from weathering and sedimentation processes during different stages of river floods (Al-jumaly, 2007).

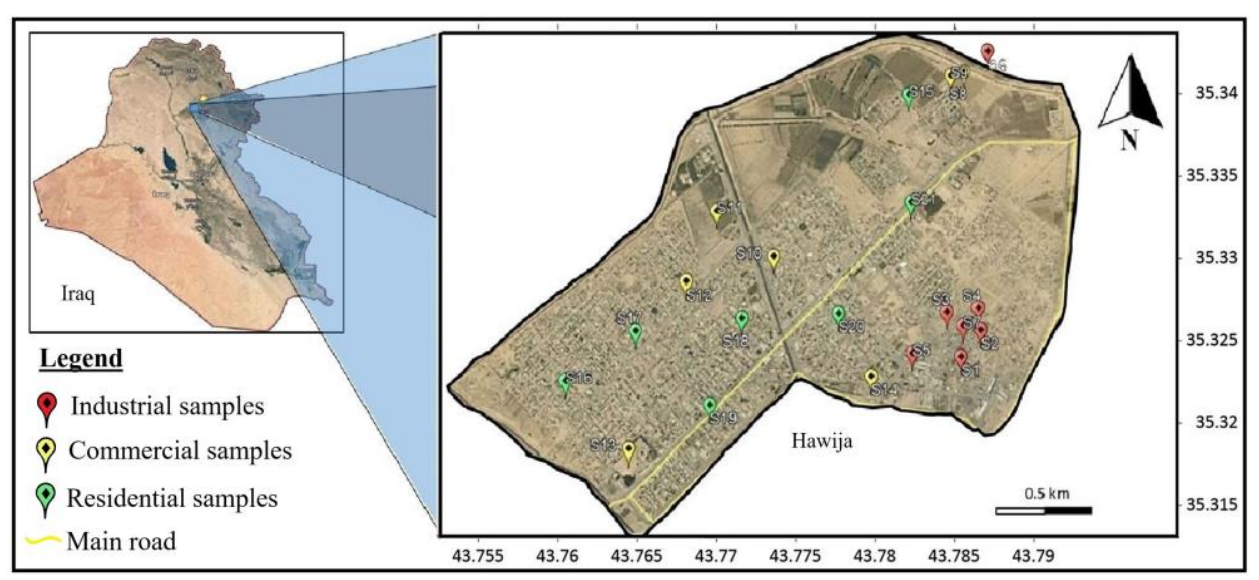

Fig. 1. Map of the study area and sampling location

\section{Sampling and Chemical Analysis}

Twenty-one samples were collected from surface soil $(0-20 \mathrm{~cm})$ in Al-Hawija (Table 1) at 10 September 2019. Every $1 \mathrm{~kg}$ of the sample is collected by Auger and saved in plastic container. In laboratory work the samples were dried using an electric oven on $55^{\circ} \mathrm{C}$ till completely dry and then grinded and sifted by sieve mesh 200 (75 Micron) then the samples are divided into three groups based on the type of land use in residential, commercial and industrial areas, then 0.5 grams of each sample was sent to ACME laboratories in Canada for the chemical analysis by inductively coupled plasma mass spectrometry (ICP-MS) (Table 2).

\section{Size Fraction}

For the purpose of studying the concentration of heavy metals and understanding their behavior in the size fraction of the study area, six soil samples (S1, S5, S9, S11, S15 and S20) were chosen and separated volumetrically into Sand, Silt and Clay using a method of pipet analysis according to (Carver, 1971) and sent to ACME laboratories for the purpose of analyzing the concentrations of heavy metals in them.

\section{Statistical Analysis}

\section{Correlation coefficient}

The correlation coefficient was calculated to find the correlations between heavy metals, as it is one of the most common statistical processes in the interpretation of geochemical relations between elements and is used to determine the possibility of a similar source of two or more elements (Wang et al., 2012). 
Table 1. Longitude and latitude of the samples

\begin{tabular}{|c|c|c|c|}
\hline Samples & Areas & Longitude & Latitude \\
\hline S1 & Industrial & $43^{\circ} 47^{\prime} 4.12^{\prime \prime}$ & $35^{\circ} 19^{\prime} 18.33^{\prime \prime}$ \\
\hline S2 & Industrial & $43^{\circ} 47^{\prime} 9.17^{\prime \prime}$ & $35^{\circ} 19^{\prime} 23.15^{\prime \prime}$ \\
\hline S3 & Industrial & $43^{\circ} 47^{\prime} 1.13^{\prime \prime}$ & $35^{\circ} 19^{\prime} 26.64^{\prime \prime}$ \\
\hline S4 & Industrial & $43^{\circ} 47^{\prime} 8.84^{\prime \prime}$ & $35^{\circ} 19^{\prime} 27.28^{\prime \prime}$ \\
\hline S5 & Industrial & $43^{\circ} 46^{\prime} 52.17^{\prime \prime}$ & $35^{\circ} 19^{\prime} 19.19^{\prime \prime}$ \\
\hline S6 & Industrial & $43^{\circ} 47^{\prime} 6.00^{\prime \prime}$ & $35^{\circ} 20^{\prime} 37.00^{\prime \prime}$ \\
\hline S7 & Industrial & $43^{\circ} 47^{\prime} 4.97^{\prime \prime}$ & $35^{\circ} 19^{\prime} 24.04^{\prime \prime}$ \\
\hline S8 & Commercial & $43^{\circ} 47^{\prime} 8.25^{\prime \prime}$ & $35^{\circ} 20^{\prime} 12.79^{\prime \prime}$ \\
\hline S9 & Commercial & $43^{\circ} 47^{\prime} 4.75^{\prime \prime}$ & $35^{\circ} 20^{\prime} 12.07^{\prime \prime}$ \\
\hline S10 & Commercial & $43^{\circ} 46^{\prime} 18.74^{\prime \prime}$ & $35^{\circ} 19^{\prime} 37.75^{\prime \prime}$ \\
\hline S11 & Commercial & $43^{\circ} 46^{\prime} 4.75^{\prime \prime}$ & $35^{\circ} 19^{\prime} 46.63^{\prime \prime}$ \\
\hline S12 & Commercial & $43^{\circ} 45^{\prime} 56.91 "$ & $35^{\circ} 19^{\prime} 33.44^{\prime \prime}$ \\
\hline S13 & Commercial & $43^{\circ} 45^{\prime} 42.84^{\prime \prime}$ & $35^{\circ} 19^{\prime} 3.01^{\prime \prime}$ \\
\hline S14 & Residential & $43^{\circ} 46^{\prime} 41.91 "$ & $35^{\circ} 19^{\prime} 15.05^{\prime \prime}$ \\
\hline S15 & Residential & $43^{\circ} 46^{\prime} 53.71^{\prime \prime}$ & $35^{\circ} 20^{\prime} 8.40^{\prime \prime}$ \\
\hline S16 & Residential & $43^{\circ} 45^{\prime} 27.22^{\prime \prime}$ & $35^{\circ} 19^{\prime} 15.55^{\prime \prime}$ \\
\hline S17 & Residential & $43^{\circ} 45^{\prime} 44.46^{\prime \prime}$ & $35^{\circ} 19^{\prime} 24.46^{\prime \prime}$ \\
\hline S18 & Residential & $43^{\circ} 46^{\prime} 10.55^{\prime \prime}$ & $35^{\circ} 19^{\prime} 26.37^{\prime \prime}$ \\
\hline S19 & Residential & $43^{\circ} 46^{\prime} 2.56^{\prime \prime}$ & $35^{\circ} 19^{\prime} 10.58^{\prime \prime}$ \\
\hline S20 & Residential & $43^{\circ} 46^{\prime} 34.29^{\prime \prime}$ & $35^{\circ} 19^{\prime} 26.84^{\prime \prime}$ \\
\hline S21 & Residential & $43^{\circ} 46^{\prime} 53.27^{\prime \prime}$ & $35^{\circ} 19^{\prime} 47.47^{\prime \prime}$ \\
\hline
\end{tabular}

Table 2. Detected limit, accuracy and precision

\begin{tabular}{|c|c|c|c|c|c|c|}
\hline Metals & Unit & Minimum Detected Limit & $\begin{array}{c}\text { STD BVGEO01 } \\
\text { Standard }\end{array}$ & $\begin{array}{c}\text { STD BVGEO01 } \\
\text { Expected }\end{array}$ & Soil S1 & $\begin{array}{c}\text { Repeated } \\
\text { Soil S1 }\end{array}$ \\
\hline $\mathrm{As}$ & $\mathrm{ppm}$ & 0.1 & 122.5 & 121 & 5.8 & 5.6 \\
\hline $\mathrm{Cd}$ & $\mathrm{ppm}$ & 0.01 & 6.43 & 6.5 & 0.46 & 0.52 \\
\hline $\mathrm{Co}$ & $\mathrm{ppm}$ & 0.1 & 25 & 25 & 13.3 & 13.5 \\
\hline $\mathrm{Cr}$ & $\mathrm{ppm}$ & 0.5 & 167.5 & 171 & 77.5 & 80.5 \\
\hline $\mathrm{Cu}$ & $\mathrm{ppm}$ & 0.01 & 4380.09 & 4415 & 55.62 & 55.18 \\
\hline $\mathrm{Fe}$ & $\%$ & 0.01 & 3.63 & 3.7 & 2.23 & 2.23 \\
\hline $\mathrm{Mn}$ & $\mathrm{ppm}$ & 1 & 10.57 & 733 & 570 & 589 \\
\hline $\mathrm{Mo}$ & $\mathrm{ppm}$ & 0.01 & 154.5 & 10.8 & 1.15 & 1.17 \\
\hline $\mathrm{Ni}$ & $\mathrm{ppm}$ & 0.1 & 191.01 & 163 & 94.5 & 95.7 \\
\hline $\mathrm{Pb}$ & $\mathrm{ppm}$ & 0.01 & 1719.7 & 1741 & 68.41 & 67.05 \\
\hline $\mathrm{Zn}$ & $\mathrm{ppm}$ & 0.1 & & & 184.4 & 185.6 \\
\hline
\end{tabular}

The higher correlation coefficient value (r) it is possible to rely Accordingly, the strong positive relationship indicates the similarity of the source to those elements, but if the relationship is strong negative, it may indicate different sources, while weak relations, the value of the value ( $r$ ) from zero indicate the diversity of sources and have no statistical significance (Guo et al., 2019). 


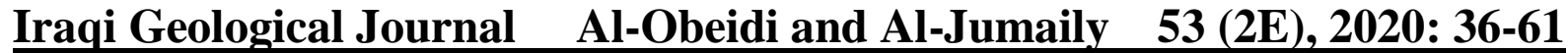

\section{Factor analysis}

Factor analysis were done using Microsoft Excel (XLSTAT 2019) program as it is one of the most important statistical methods for analyzing multiple variables, as it works to reduce the number of variables while preserving the variations of the original variables and giving joint factors that simplify the relationship between the variables and help explain them.

\section{Indices Assessment}

\section{Contamination factor (CF) and degree of contamination (DoC)}

The contamination factor is established by Hakanson (1980) and calculated by equation 1, and it is classified into ranges as in Table 3 which can be:

$$
C F_{i}=\frac{C_{i}}{B_{i}}
$$

Where $\mathrm{Ci}$ is the concentration of the element in the soil and $\mathrm{Bi}$ is the background of the element in the soil. In this study, the average concentration of elements in the soil was used according to what was previously published (Kabata-Pendias and Mukherjee, 2007). Since the contamination factor only reveals contamination of a single element, the sum of the pollution factors for all the elements examined represents the DoC in the environment (Hakanson, 1980; Inengite et al., 2015), and is divided into four categories as in the Table 3 and calculated by equation 2:

$$
D o C=\sum_{i}^{n} C F
$$

Where CF contamination factor and n number of heavy metals in the study .

\section{Geoaccumulation index (Igeo)}

The Geoaccumulation index is proposed by Muller (1969) to assess soil contamination with heavy metals which depends on the concentration of elements in its background of the environment including very low human inputs, and is calculated by multiplying the background value concentration by a factor of 1.5 to get the upper limit than lowest class as in equation 3 (Kowalska et al., 2018; Muller, 1969; Wei and Yang, 2010).

$$
I_{g e o}=\log _{2}\left(C_{i} / 1.5 B_{i}\right)
$$

Where $\mathrm{Ci}$ is the concentration of the measured element in the soil and $\mathrm{Bi}$ is the background for it in the soil, and the constant 1.5 is added to analyze the natural variation in the environmental units to discover very small human impacts, and it is classified into seven classes as in Table 3. 
Table 3. Classification of environmental indicators

\begin{tabular}{|c|c|c|c|}
\hline Index & Value & Environmental risk grade & Reference \\
\hline \multirow[t]{4}{*}{$\mathrm{CF}$} & $\mathrm{CF}<1$ & Low contamination factor & \multirow[t]{4}{*}{ (Hakanson, 1980) } \\
\hline & $1 \leq \mathrm{CF}<3$ & Moderate contamination factor & \\
\hline & $3 \leq \mathrm{CF}<6$ & Considerable contamination factor & \\
\hline & $\mathrm{CF} \geq 6$ & Very high contamination factor & \\
\hline \multirow[t]{4}{*}{$\mathrm{DoC}$} & Doc $<8$ & Low Doc & \multirow[t]{4}{*}{ (Hakanson, 1980) } \\
\hline & $8 \leq \mathrm{DoC}<16$ & Moderate Doc & \\
\hline & $16 \leq$ Doc $<32$ & Considerable Doc & \\
\hline & $\mathrm{DoC} \geq 32$ & High Doc & \\
\hline \multirow[t]{7}{*}{ Igeo } & $\mathrm{I}_{\mathrm{geo}} \leq 0$ & Uncontaminated (Class 0) & \multirow[t]{7}{*}{ (Muller, 1969) } \\
\hline & $0<\mathrm{I}_{\mathrm{geo}} \leq 1$ & Uncontaminated to moderately contaminated (Class 1) & \\
\hline & $1<\mathrm{I}_{\text {geo }} \leq 2$ & Moderately contaminated (Class 2) & \\
\hline & $2<\mathrm{I}_{\mathrm{geo}} \leq 3$ & Moderately to heavily contaminated (Class 3 ) & \\
\hline & $3<\mathrm{I}_{\mathrm{geo}} \leq 4$ & Heavily contaminated (Class 4) & \\
\hline & $4<\mathrm{I}_{\mathrm{geo}} \leq 5$ & Heavily to extremely contaminated (Class 5) & \\
\hline & $5<\mathrm{I}_{\mathrm{geo}}$ & Extremely contaminated (Class 6) & \\
\hline \multirow[t]{3}{*}{ PLI } & $<1$ & Not pollution & \multirow{3}{*}{$\begin{array}{l}\text { (Tomlinson et al., } \\
1980)\end{array}$} \\
\hline & $=1$ & Baseline levels of pollution & \\
\hline & $>1$ & Pollution & \\
\hline \multirow[t]{5}{*}{$\mathrm{Er}$} & $\mathrm{Er}<40$ & Low potential ecological risk & \multirow[t]{5}{*}{ (Hakanson, 1980) } \\
\hline & $40 \leq \operatorname{Er}<80$ & Moderate potential ecological risk & \\
\hline & $80 \leq \operatorname{Er}<160$ & Considerable potential ecological risk & \\
\hline & $160 \leq \operatorname{Er}<320$ & High potential ecological risk & \\
\hline & $\mathrm{Er} \geq 320$ & Very high ecological risk & \\
\hline \multirow[t]{4}{*}{ RI } & $\mathrm{RI}<150$ & Low ecological risk & \multirow[t]{4}{*}{ (Hakanson, 1980) } \\
\hline & $150 \leq \mathrm{RI}<300$ & Moderate ecological risk & \\
\hline & $300 \leq \mathrm{RI}<600$ & Considerable ecological risk & \\
\hline & $\mathrm{RI} \geq 600$ & Very high ecological risk & \\
\hline
\end{tabular}

\section{Pollution load index (PLI)}

Defined as criterion of the total pollution level at the sample site. Developed by Tomlinson et al. (1980). It is possible to estimate heavy metal pollution levels for different sampling sites, and can calculated by equation 4 :

$$
P L I=\left(C F_{1} \times C F_{2} \times \ldots \times C F_{n}\right)^{1 / n}
$$

Where $\mathrm{n}$ is the number of metals studied, CF is a contamination factor and PLI is classified into three categories (Table 3).

\section{Potential ecological risk index (RI)}

It is the an indicator used to determine the potential environmental risks of heavy metals on living organisms in the environment (soil, water and air) (Al-Anbari et al., 2015; Guan et al., 2014; Kowalska et al., 2018 and Tang et al., 2015). 
RI is calculated by the sum of the Ecological Risk (Er) of each sample by equation 5 and 6 (Hakanson, 1980).

$$
\begin{aligned}
& E_{r}=T_{r} \times C F \\
& R I=\sum_{i}^{n} E_{r}^{i}
\end{aligned}
$$

Where CF represents the contamination factor, Tr represents the coefficient of toxicity of the elements which is $\mathrm{As}=10, \mathrm{Cd}=30, \mathrm{Cr}=2, \mathrm{Cu}=5$ and $\mathrm{Pb}=5$ (Hakanson, 1980), $\mathrm{n}$ is number of the elements, and was previously classified into the four categories (Table 3 )

\section{RESULTS AND DISCUSSION}

\section{Geochemical Distribution of Heavy Metals in Surface Soil}

Arsenic (As)

It's average in the soil was $6.4 \mathrm{mg} / \mathrm{kg}$ (Table 4) which is higher than the background value for it in the earth crust, which is $1.8 \mathrm{mg} / \mathrm{kg}$ (Kabata-Pendias and Mukherjee, 2007), the highest concentration was in the industrial areas in the site of S6 represented by Technical Institute workshop which attacked by Military operations (Dvorak et al., 2020), while the sites S2, S3, and S4, may be resulted by industrial waste product from repairing workshops (Thornton, 1996), but in the commercial area was its highest concentration in the site S8 and this is also due to the military operation because it represents the Deanship of the Technical Institute in the northeast of the town (Fig. 2) while the site S14 was related to the heavy traffic because it represents the bus station area in the south the town (Nannoni et al., 2011), and the highest concentration of arsenic in residential areas was at the sites S15 and S21 may be related to the military operations at site S15, while site S21 may be due to the use of pesticides (Thornton, 1996), generally the arsenic in the industrial, commercial and residential areas was relatively high, and this explains the role of military operations.

\section{Cadmium (Cd)}

The average concentration of the cadmium in the surface soil of Al-Hawija town $(0.31 \mathrm{mg} / \mathrm{kg})$ (Table 4) which is higher than its background value for the Earth's crust $(0.1-0.2 \mathrm{mg} / \mathrm{kg})$, As for the average soil concentration $(0.5 \mathrm{mg} / \mathrm{kg}$ ) it was relatively normal (Kabata-Pendias and Mukherjee, 2007), the highest concentration was in the industrial area (site S1 and S7) (Fig. 2) due to their proximity to the grain mill and repairing garage as they have chemical's waste product plus heavy traffic (Jaradat and Momani, 1999), and in the site S3 Cd source was due to the military operation there, this is compatible with Islam et al. (2016) as it was stated that the shooting areas increase the percentage of cadmium in the surface soil, in the commercial 
areas the highest concentration was in the site S14 (bus station) due to heavy traffic (Yakeem and Onifade, 2012), in residential areas it reached $0.52 \mathrm{mg} / \mathrm{kg}$ in the site $\mathrm{S} 21$ due to the use of fertilizers and pesticides as well as the proximity from an electric generator (small farm) (Adriano, 2001), In general the concentration of cadmium in industrial areas was higher than that of residential and commercial areas, as it reached $0.33>0.32>0.26$, respectively.

Table 4. Concentrations and of heavy metals in surface soil samples

\begin{tabular}{|c|c|c|c|c|c|c|c|c|c|c|c|}
\hline \multirow{2}{*}{ Sample No } & As & Cd & Co & $\mathrm{Cr}$ & $\mathbf{C u}$ & $\mathbf{F e}$ & Mn & Mo & $\mathbf{N i}$ & $\mathbf{P b}$ & Zn \\
\hline & $\mathrm{mg} / \mathrm{kg}$ & $\mathrm{mg} / \mathrm{kg}$ & $\mathrm{mg} / \mathrm{kg}$ & $\mathrm{mg} / \mathrm{kg}$ & $\mathrm{mg} / \mathrm{kg}$ & $\%$ & $\mathrm{mg} / \mathrm{kg}$ & $\mathrm{mg} / \mathrm{kg}$ & $\mathrm{mg} / \mathrm{kg}$ & $\mathrm{mg} / \mathrm{kg}$ & $\mathrm{mg} / \mathrm{kg}$ \\
\hline \multicolumn{12}{|c|}{ Industrial Area } \\
\hline S1 & 5.8 & 0.46 & 13.3 & 77.5 & 55.62 & 2.23 & 570 & 1.15 & 94.5 & 68.41 & 184.4 \\
\hline $\mathrm{S} 2$ & 6.7 & 0.33 & 18.9 & 97.2 & 105.94 & 3.21 & 828 & 1.42 & 136.2 & 49.37 & 186.9 \\
\hline $\mathrm{S} 3$ & 6.7 & 0.39 & 16.5 & 85.1 & 34.89 & 2.57 & 578 & 0.77 & 121 & 53.23 & 108.6 \\
\hline S4 & 6.7 & 0.24 & 14.5 & 76.8 & 23.27 & 2.29 & 561 & 0.62 & 106.1 & 8.05 & 46.5 \\
\hline S5 & 6.2 & 0.18 & 18.1 & 91.8 & 38.35 & 2.78 & 727 & 0.7 & 144.7 & 14.65 & 55.3 \\
\hline S6 & 7.3 & 0.31 & 17.5 & 89.9 & 27.85 & 2.62 & 630 & 0.8 & 121.5 & 9.59 & 57.8 \\
\hline S7 & 6.6 & 0.46 & 17.9 & 93.6 & 90.48 & 2.59 & 708 & 1.55 & 124.6 & 347.9 & 175.4 \\
\hline Average & 6.6 & 0.3 & 16.7 & 87.4 & 53.8 & 2.6 & 657.4 & 1.0 & 121.2 & 78.8 & 116.4 \\
\hline \multicolumn{12}{|c|}{ Commercial Area } \\
\hline S8 & 7.5 & 0.28 & 17.6 & 89.3 & 27.24 & 2.5 & 609 & 1.06 & 119.3 & 9.82 & 53.9 \\
\hline S9 & 6.2 & 0.26 & 17.6 & 90.3 & 43.89 & 2.67 & 699 & 0.47 & 136.9 & 13.37 & 136.2 \\
\hline S10 & 6.9 & 0.27 & 16.6 & 79.7 & 26.15 & 2.41 & 651 & 0.61 & 122.6 & 9.33 & 51.8 \\
\hline S11 & 6.4 & 0.32 & 18.7 & 93.3 & 34.16 & 2.87 & 669 & 0.56 & 134.5 & 12.11 & 69.7 \\
\hline S12 & 6.1 & 0.27 & 15.6 & 71.5 & 30.89 & 2.22 & 713 & 0.83 & 103.4 & 18.46 & 80.9 \\
\hline S13 & 6 & 0.16 & 17.5 & 87.2 & 26.26 & 2.52 & 718 & 0.39 & 133.1 & 8.04 & 47.9 \\
\hline S14 & 7.3 & 0.31 & 17.6 & 89 & 32.61 & 2.47 & 591 & 0.85 & 116.2 & 27.88 & 68 \\
\hline Average & 6.6 & 0.3 & 17.3 & 85.8 & 31.6 & 2.5 & 664.3 & 0.7 & 123.7 & 14.1 & 72.6 \\
\hline \multicolumn{12}{|c|}{ Residential Area } \\
\hline S15 & 6.7 & 0.32 & 17.5 & 93.1 & 40.55 & 2.74 & 663 & 0.76 & 125.8 & 41.23 & 81.5 \\
\hline S16 & 6.3 & 0.24 & 16.9 & 80.6 & 27.92 & 2.29 & 598 & 0.87 & 113.9 & 18.65 & 61.2 \\
\hline S17 & 6.2 & 0.36 & 16 & 81.1 & 38.81 & 2.28 & 663 & 0.6 & 110.2 & 78 & 134.4 \\
\hline S18 & 6.2 & 0.27 & 16.1 & 80.1 & 28.42 & 2.4 & 710 & 0.53 & 117.6 & 17.03 & 82.2 \\
\hline S19 & 6.1 & 0.29 & 16.2 & 89.7 & 32.54 & 2.6 & 702 & 0.47 & 119.4 & 28.04 & 77.56 \\
\hline $\mathrm{S} 20$ & 5.7 & 0.27 & 17.2 & 88.8 & 33.09 & 2.57 & 631 & 0.45 & 125.8 & 68.75 & 101.2 \\
\hline S21 & 6.7 & 0.52 & 17.6 & 87 & 31.26 & 2.5 & 614 & 0.68 & 114.4 & 24.38 & 82.2 \\
\hline Average & 6.3 & 0.3 & 16.8 & 85.8 & 33.2 & 2.5 & 654.4 & 0.6 & 118.2 & 39.4 & 88.6 \\
\hline Max & 7.5 & 0.52 & 18.9 & 97.2 & 105.94 & 3.21 & 828 & 1.55 & 144.7 & 347.9 & 186.9 \\
\hline Min & 5.7 & 0.16 & 13.3 & 71.5 & 23.27 & 2.22 & 561 & 0.39 & 94.5 & 8.04 & 46.5 \\
\hline Average & 6.4 & 0.31 & 16.9 & 86.3 & 39.5 & 2.54 & 658.7 & 0.77 & 121.0 & 44.1 & 92.5 \\
\hline $\begin{array}{l}\text { (Kabata-Pendias } \\
\text { and Mukherjee, } \\
\text { 2007) }\end{array}$ & 1.8 & 0.5 & $\begin{array}{c}4.5- \\
14\end{array}$ & 54 & 20 & 3.5 & $\begin{array}{c}10- \\
9000\end{array}$ & 1.8 & 22 & 25 & 64 \\
\hline
\end{tabular}




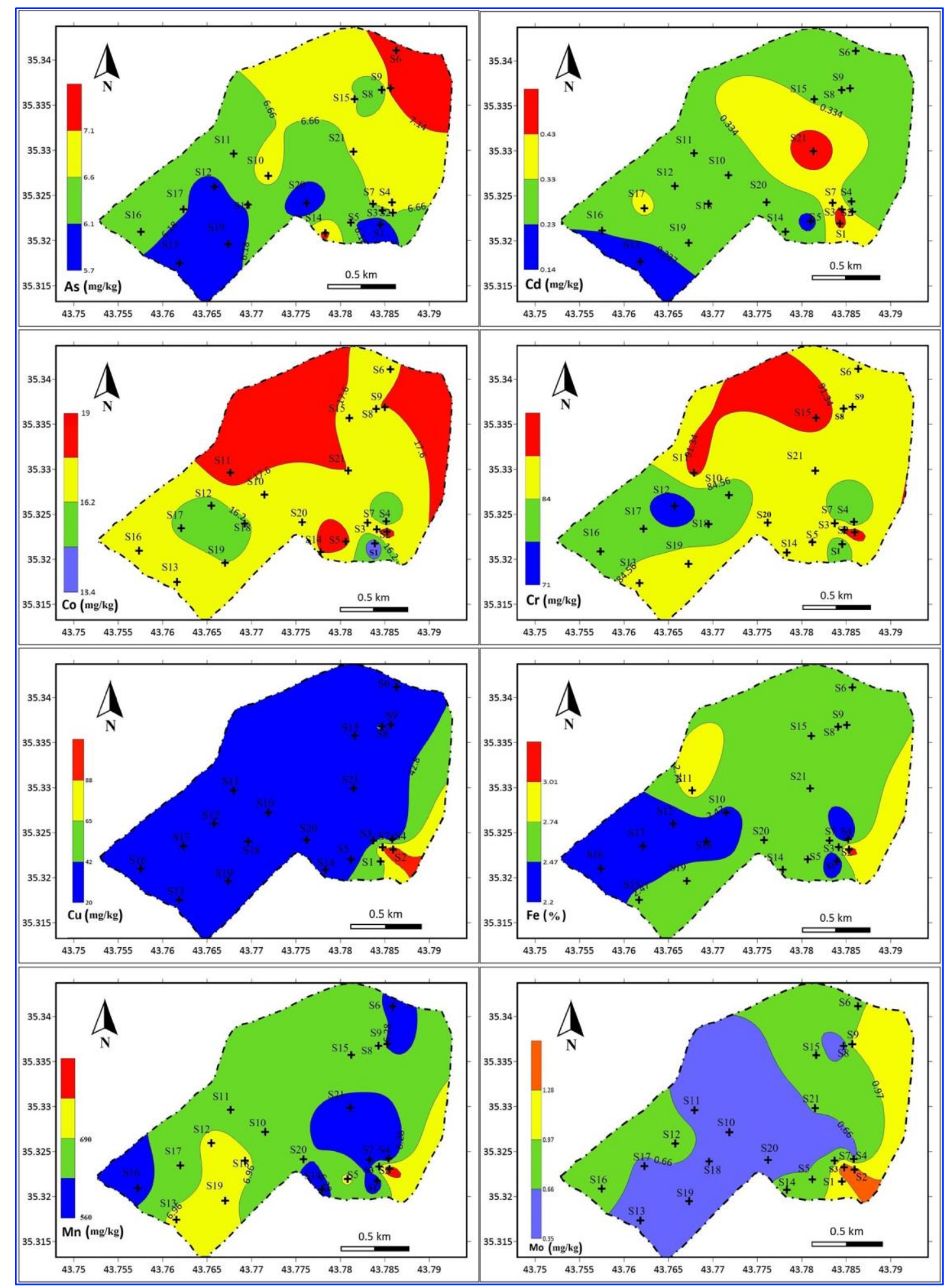

Fig .2. Spatial distribution of $\mathrm{As}, \mathrm{Cd}, \mathrm{Co}, \mathrm{Cr}, \mathrm{Cu}, \mathrm{Fe}, \mathrm{Mn}$ and $\mathrm{Mo}$ in the top soil of the study area

\section{Cobalt (Co)}

Its average concentration was $16.9 \mathrm{mg} / \mathrm{kg}$ (Table 4), which is higher than the background of the soil (4.5 to $14 \mathrm{mg} / \mathrm{kg}$ ) (Kabata-Pendias and Mukherjee, 2007), it was relatively similar in the most of sites of industrial area, it was higher in the site $\mathrm{S} 2$ and $\mathrm{S} 7(18.9,18.1 \mathrm{mg} / \mathrm{kg})$ 
respectively, due to car's emissions and industrial liquid waste product (oils and chemical detergents) (Al-Khashman, 2007). For the commercial areas it's concentration reached was $18.7 \mathrm{mg} / \mathrm{kg}$ in the site $\mathrm{S} 11$ (Fig. 2) which represent vegetables and fruits store, phosphatic fertilizers are a source of cobalt that may be carried with these crops (Zadnipryany et al., 2017). In residential areas (S21 and S15 sites) its concentration was $17.6 \mathrm{mg} / \mathrm{kg}$ and 17.5 respectively, due to sewage sludge and the construction debris (Leyssens et al., 2017), in the commercial areas that's located in the east and north of the town was higher than it is in residential and industrial areas.

\section{Chromium (Cr)}

The average concentration of the $\mathrm{Cr}$ in the surface soil $(86.3 \mathrm{mg} / \mathrm{kg})$ (Table 4) was higher than the background value in the soil and reached $54 \mathrm{mg} / \mathrm{kg}$ (Kabata-Pendias and Mukherjee, 2007), the highest concentration of the element in the industrial areas of the site S2 was due to the liquid waste product containing dyes, because the chromium is used in the production of steel, electroplating and some specialized chemical materials (Ertani et al., 2017), sites S7 and S5, which may also due to chemical waste product and dyes, while residential areas have higher concentration in the site S11 and S9 as a result of military operations against terrorism (Mishra and Bharagava, 2016; Idzelis et al., 2006), which lead to an increase in mineral waste in the surface soil, in residential areas the chromium component was concentrated in the north of AlHawija in site S15 (Fig. 2), which also returns to the Technical Institute near the student's housing, (attacked by military operations), in general the average concentration of chromium in the industrial areas $(87.4 \mathrm{mg} / \mathrm{kg})$, which is higher than that in the commercial and residential areas $(85.7 \mathrm{mg} / \mathrm{kg})$.

\section{Copper $(\mathrm{Cu})$}

The average of copper concentration was $39.53 \mathrm{mg} / \mathrm{kg}$ (Table 4) which is higher than the background value of $20 \mathrm{mg} / \mathrm{kg}$ (Kabata-Pendias and Mukherjee, 2007), as the highest concentration was in the southeast of the town (Fig. 2) specifically at S2 and S7 sites and this may be related to the liquid and solid industrial waste there (Rajaganapathy et al., 2011), and it's also appeared in high concentration in the S1 site and this may be due to its proximity to the high way (Kabadayi and Cesur, 2010). For the residential areas, its highest concentration was in the S15 site, which is near the student housing of the Technical Institute, or may be due to the military operations in the area. In the commercial areas reached its highest concentration in the S9 site (near the building of the Deanship of the Technical Institute, Al- Hawija), due to military operation occurred there (Dvorak et al., 2020; Vasarevičius and Greičiūte, 2004), and 
in general the industrial areas show higher concentrations than the residential and commercial areas, its sequence was 53>33>31, respectively.

\section{Iron $(\mathrm{Fe})$}

Its average concentration in surface soil reached $2.54 \%$ (Table 4) and these concentrations are less than the background value of the elemental concentration in the soil, which is $3.5 \%$ (Kabata-Pendias and Mukherjee, 2007), it concentration in industrial areas in the site S2 is 3.2 $\%$ (Fig. 2), this is probably due to the presence of waste product of cars repairing garage, in addition to the results of the frictions of the brakes (Thorpe and Harrison, 2008), for the rest of the industrial and commercial sites of residential areas all of them were less than $2.87 \%$ and this percentage is relatively low because iron is a widespread element in the soil as it is the third most common metal in the Earth's crust (Wedepohl, 1995), in general the variation in rates was relatively slight as the element showed a concentration in soil sites of industrial areas were higher than the commercial and residential areas, which was $2.61>2.52>2.48$, respectively.

\section{Manganese (Mn)}

Its average soil surface concentration was $658 \mathrm{mg} / \mathrm{kg}$ (Table 4) which is within soil background value of $10-9000 \mathrm{mg} / \mathrm{kg}$ (Kabata-Pendias and Mukherjee, 2007). There is no contamination of manganese in the surface soil in Al-Hawija town.

\section{Molybdenum (Mo)}

The average of molybdenum concentration was $0.76 \mathrm{mg} / \mathrm{kg}$ (Table 4) which is less than background in the soil $(1.8 \mathrm{mg} / \mathrm{kg}$ ) (Kabata-Pendias and Mukherjee, 2007), it was the highest concentrations in the industrial areas in the site of S7 and S2 as compared to other sites (Fig. 2) and this is may be due to liquid waste originating from car's repair and the use of chemical detergents (Liang et al., 2017; Xu et al., 2013). For the commercial and residential areas, Mo concentration was relatively normal to its concentration in the background, in general the rate in the industrial areas was higher than that the commercial and residential areas, its sequence was $1>0.68>0.62$, respectively.

Nickel $(\mathrm{Ni})$

Its average concentration in soil reached $121 \mathrm{mg} / \mathrm{kg}$ (Table 4), which is higher than the background value of the element $(20 \mathrm{mg} / \mathrm{kg}$ ) (Kabata-Pendias and Mukherjee, 2007), Ni is highly affected by paedogenic (Sun et al., 2018) it was observed in the town but more in the residential areas (located in the center, north and the southeast area of the town), its highest concentration in the industrial site S2 and S5 (136.2, $144.7 \mathrm{mg} / \mathrm{kg}$ ) respectively (Fig.3), due to its waste product, Terry and Banuelos (2000) mentioned that nickel is used in steel industry, nickel-cadmium batteries and in electroplating. In commercial and residential areas its highest 
concentration was in the sites S 20,15, 13, 11 and 9 respectively this may be due to domestic waste and car's emissions (Rathor et al., 2014), generally the concentration of nickel in the soil of commercial areas was higher than in industrial and residential areas, which was 123.7> 121.2> 118.1 respectively (Source rocks may be rich in nickel)

\section{Lead $(P b)$}

The average of the lead concentration was $44.11 \mathrm{mg} / \mathrm{kg}$ (Table 4) which is higher than globally published (Kabata-Pendias and Mukherjee, 2007) which is $25 \mathrm{mg} / \mathrm{kg}$ and it was in high concentration in the southeastern part of the town (Fig. 3) in particular site S7, due to its proximity to the repair and garage dyeing car that have high emission of exhausts, liquid waste of oils and fuels (Awadh and Al-Hamdani, 2019; Liang et al., 2017). S1 site is the second area of the higher concentration due to its proximity to the grain mill that's work by fuel contain lead (García-Lestón et al., 2012) or may be due to the military operations occurred there (Vasarevičius and Greičiūte, 2004), and in the site S2 the concentration of the lead was reached $49.36 \mathrm{mg} / \mathrm{kg}$ and the reason due to its proximity to the car washing garage, for the site $\mathrm{S} 3 \mathrm{which}$ has a concentration of $53.23 \mathrm{mg} / \mathrm{kg}$. This is due to its proximity to Al-Hawija electric substation and Al-Taleea fuel station (de Miguel et al., 1997), the fuel contains lead increase its emission, in residential areas it's higher concentration in the site S17 due to its proximity to an electric generator, for the commercial areas the higher concentration at the site S14, which represents bus station (high traffic emissions), generally the industrial areas show higher concentrations than in commercial and residential areas, its sequence was $78.75>39.44>14.14$, respectively.

\section{Zinc (Zn)}

The average concentration of zinc in Al-Hawija surface soil is $92.55 \mathrm{mg} / \mathrm{kg}$ (Table 4), which is higher than its average in the soil (64mg/kg) (Kabata-Pendias and Mukherjee, 2007), the highest concentration in the industrial areas are in sites S2, S1 and S7 (Fig. 3), This is may be due to the friction of the tires and multiple use of brake as zinc is used in their manufacture (Taghavi et al., 2019), In addition to that zinc can be produced from car's oil, cooling fluids and road erosion (Saeedi et al., 2009), The commercial area was the highest concentration $(136.2 \mathrm{mg} / \mathrm{kg}$ ) in the site S9 that's may be due to military operations (attacked by heavy weapons) (Islam et al., 2016), and in residential areas the highest concentration was $134.4 \mathrm{mg} / \mathrm{kg}$ in the site S17 due to its proximity to un electric generator and the presence of domestic waste product (AlJumaily and Rasheed, 2018), in general the rate of its concentration in industrial areas was higher than that in residential and commercial areas $116.4>88.6>72.6$, respectively. 


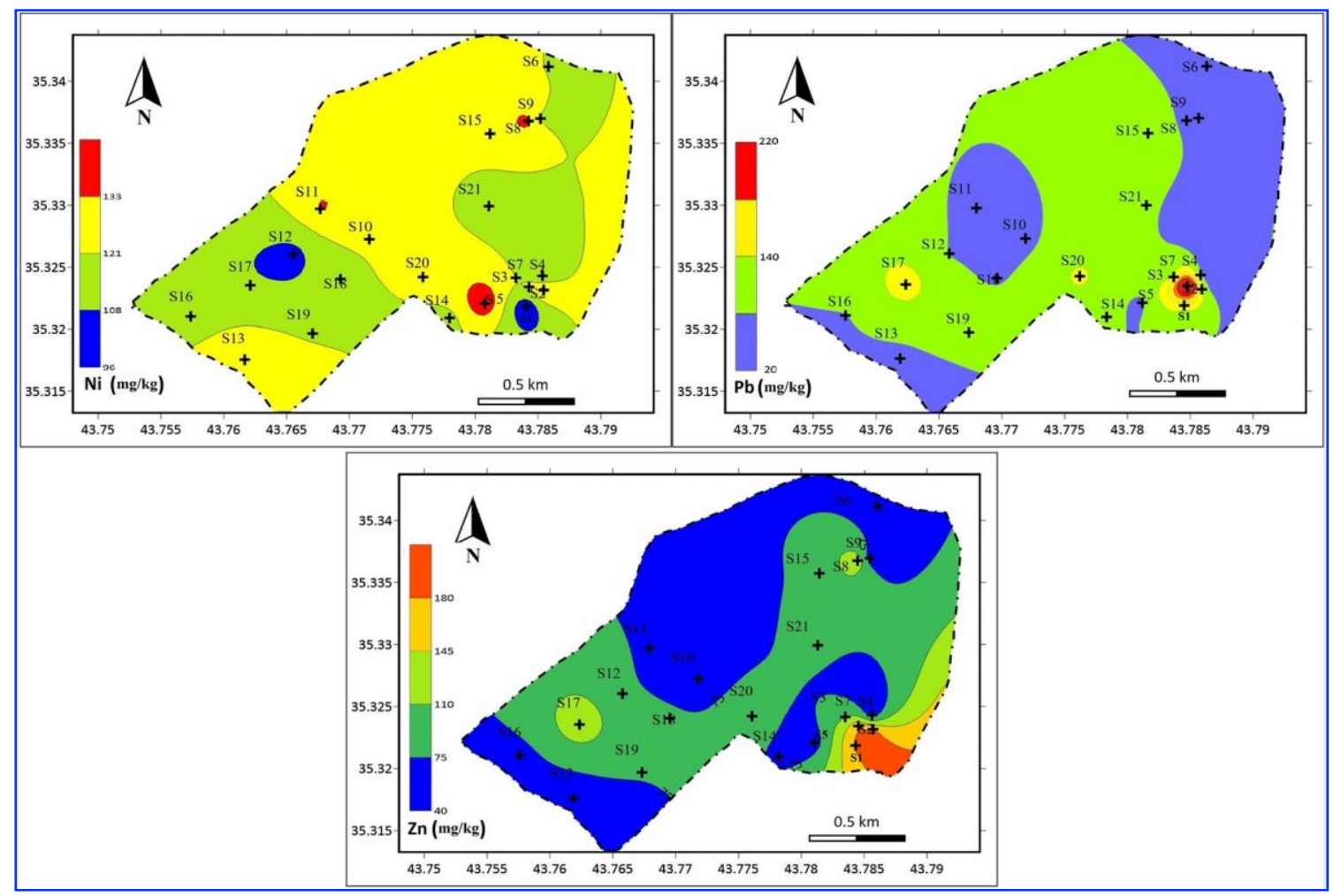

Fig. 3. Spatial distribution of $\mathrm{Ni}, \mathrm{Pb}$ and $\mathrm{Zn}$ in the top soil of the study area

\section{Size Distribution Effect}

The size of soil particles has an important and effective role in determining the content and movement of heavy metals in the soil (Rinklebe et al., 2016; Shaheen and Rinklebe, 2014), as these elements are concentrated in the clay part more than in the silty and sandy part (Bhattacharyya and Gupta, 2008), this is due to the fact that iron oxides, manganese, clay minerals and organic matter are concentrated in the fine parts that adsorption, absorption, sedimentation, and ion exchange of heavy metals (Awadh et al., 2015; Liu et al., 2018), Gong et al. (2014) stated that there is an inverse proportion between heavy metal concentration and the size of the soil grains, the soil grain was of silt loam category and all the studied heavy metals were focused on very fine granular, as their concentration increased in clay more than silt and sand, the concentrations of copper, zinc and lead in the clay fraction were increased due to its adsorption on clay minerals, and those metals were adsorbed on Bentonite and Montmorillonite minerals (Table 5) (Jin et al., 2014; Akpomie and Dawodu, 2016; El Adraa et al., 2017), while nickel rose in Clay as a result of replacing iron and magnesium in the crystal structure of kaolinite and montmorillonite minerals (Addy et al., 2012; Mohammed and AlMashaikie, 2018), and the cobalt is adsorbed on the surfaces of smectite and clay minerals (Shawabkeh et al., 2007), also cadmium may be was adsorbed by kaolinite (Awadh and Yousif, 2015), arsenic and cobalt may be concentrated in the clay part due to the high adsorption of clay minerals in general (Argyraki et al., 2017; Xu et al., 2019). 
Iraqi Geological Journal Al-Obeidi and Al-Jumaily 53 (2E), 2020: 36-61

Table 5. Results of the analysis of the heavy metals in size distribution for the soil

\begin{tabular}{|c|c|c|c|c|c|c|c|c|c|c|c|c|}
\hline \multirow{2}{*}{ Size } & Metals & Mo & $\mathbf{C u}$ & $\mathbf{P b}$ & Zn & $\mathbf{N i}$ & Co & Mn & $\mathrm{Fe}$ & As & Cd & $\mathrm{Cr}$ \\
\hline & Units & $\mathrm{mg} / \mathrm{kg}$ & $\mathrm{mg} / \mathrm{kg}$ & $\mathrm{mg} / \mathrm{kg}$ & $\mathrm{mg} / \mathrm{kg}$ & $\mathrm{mg} / \mathrm{kg}$ & $\mathrm{mg} / \mathrm{kg}$ & $\mathrm{mg} / \mathrm{kg}$ & $\%$ & $\mathrm{mg} / \mathrm{kg}$ & $\mathrm{mg} / \mathrm{kg}$ & $\mathrm{mg} / \mathrm{kg}$ \\
\hline \multirow{3}{*}{$\begin{array}{l}\text { Sand } \\
8.9 \%\end{array}$} & $\operatorname{Max}$ & 1.76 & 99.9 & 47.79 & 166.8 & 120.7 & 16.3 & 726 & 2.94 & 5.9 & 0.38 & 92.1 \\
\hline & Mine & 0.26 & 19.69 & 6.03 & 35.8 & 95.2 & 12.1 & 582 & 2.18 & 4 & 0.16 & 74.3 \\
\hline & Average & 0.62 & 39.08 & 21.91 & 81.1 & 111.2 & 14.4 & 621 & 2.44 & 4.9 & 0.27 & 79.4 \\
\hline \multirow{3}{*}{$\begin{array}{c}\text { Silt } \\
79.5 \%\end{array}$} & $\operatorname{Max}$ & 1.13 & 83.92 & 56.53 & 154.5 & 124.5 & 16.3 & 717 & 2.91 & 6.2 & 0.32 & 84.8 \\
\hline & Mine & 0.35 & 22.2 & 6.88 & 38.9 & 113.9 & 14.6 & 552 & 2.28 & 5 & 0.14 & 79 \\
\hline & Average & 0.57 & 39.95 & 23.23 & 87.7 & 118.8 & 15.4 & 614 & 2.49 & 5.4 & 0.25 & 81.4 \\
\hline \multirow{3}{*}{$\begin{array}{c}\text { Clay } \\
11.5 \%\end{array}$} & Max & 1.65 & 156. & 114.5 & 271.8 & 216.1 & 31 & 1153 & 4.08 & 10.6 & 0.4 & 133.6 \\
\hline & Mine & 0.61 & 50.57 & 19 & 90.9 & 170.6 & 23.7 & 790 & 3.53 & 8.3 & 0.28 & 122.8 \\
\hline & Average & 1.04 & 77.53 & 54.95 & 155.6 & 187.2 & 26.8 & 962 & 3.82 & 9.4 & 0.36 & 127.4 \\
\hline
\end{tabular}

\section{Statistical Analysis}

\section{Correlation coefficient}

The results of the correlation coefficient showed that the metals were divided into two groups (Table 6) where molybdenum was correlated with copper, lead, zinc and cadmium with positive relationships, and this may be due to the geochemical affiliation of molybdenum with copper in the copper minerals carrying it (Jeldres et al., 2017) and with the zinc and cadmium due to the similarity of their industrial sources (Liang et al., 2017; Wang et al., 2007). As for the correlation of lead with zinc, it may be due to the similarity of their anthropogenic of fuel combustion and tire friction (Lee et al., 2005; Al-Hamdani et al., 2016).

Table 6. Correlation coefficient of heavy metals in the top soil

\begin{tabular}{|c|c|c|c|c|c|c|c|c|c|c|c|}
\hline & Mo & $\mathrm{Cu}$ & $\mathbf{P b}$ & $\mathbf{Z n}$ & $\mathbf{N i}$ & Co & Mn & $\mathrm{Fe}$ & As & Cd & $\mathrm{Cr}$ \\
\hline Mo & 1 & & & & & & & & & & \\
\hline $\mathrm{Cu}$ & $.775^{\text {** }}$ & 1 & & & & & & & & & \\
\hline $\mathbf{P b}$ & $.612^{* *}$ & $.641^{* *}$ & 1 & & & & & & & & \\
\hline Zn & $.595^{* *}$ & $.837^{* *}$ & $.600^{* *}$ & 1 & & & & & & & \\
\hline $\mathbf{N i}$ & -.131 & .230 & -.017 & -.079 & 1 & & & & & & \\
\hline Co & .099 & .274 & .080 & -.087 & $.833^{* *}$ & 1 & & & & & \\
\hline Mn & .129 & $.542^{*}$ & .138 & .282 & $.592^{* *}$ & $.490^{*}$ & 1 & & & & \\
\hline $\mathbf{F e}$ & .199 & $.542^{*}$ & .039 & .217 & $.812^{* *}$ & $.775^{* *}$ & $.604^{* *}$ & 1 & & & \\
\hline As & .327 & -.037 & -.063 & -.287 & .037 & .336 & -.245 & .163 & 1 & & \\
\hline Cd & $.485^{*}$ & .407 & $.510^{*}$ & $.589^{* *}$ & -.389 & -.123 & -.247 & -.039 & .126 & 1 & \\
\hline $\mathrm{Cr}$ & .211 & $.462^{*}$ & .236 & .176 & $.776^{* *}$ & $.825^{* *}$ & .405 & $.875^{* *}$ & .260 & .066 & 1 \\
\hline
\end{tabular}

** Correlation is significant at the 0.01 level * Correlation is significant at the 0.05 level

Nickel is positively correlated with cobalt, manganese, iron and chromium, nickel correlation with cobalt may be due to the entry of the two elements in the steel industry and some household appliances (Ertani et al., 2017), or it may be attributed to the adsorption of these elements on clay minerals as well as the presence of iron oxides in its crystal structure (Gitari, 2014). 


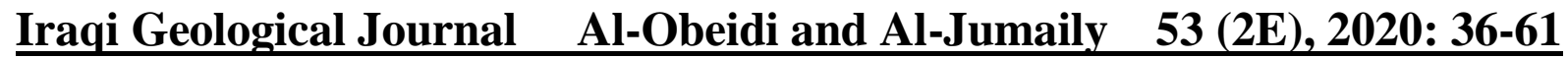

\section{Factor analysis}

Four factors were chosen, which explain $74.04 \%$ of the total variance of the variables (Table 7)

Table 7. Loading factors

\begin{tabular}{|c|c|c|c|c|c|c|c|c|c|}
\hline & F1 & F2 & F3 & F4 & & F1 & F2 & F3 & F4 \\
\hline Mo & -0.166 & 0.781 & -0.164 & -0.293 & $\mathrm{SO}_{3}$ & -0.604 & 0.204 & 0.351 & 0.073 \\
\hline $\mathrm{Cu}$ & 0.157 & 0.941 & 0.111 & -0.120 & $\mathrm{Cl}$ & -0.363 & -0.363 & 0.111 & -0.374 \\
\hline $\mathrm{Pb}$ & -0.113 & 0.747 & -0.121 & -0.068 & $\mathrm{~K}_{2} \mathrm{O}$ & 0.671 & -0.175 & -0.559 & 0.321 \\
\hline $\mathrm{Zn}$ & -0.138 & 0.882 & 0.129 & 0.229 & $\mathrm{CaO}$ & -0.747 & 0.120 & -0.081 & 0.220 \\
\hline $\mathrm{Ni}$ & 0.891 & 0.086 & 0.198 & -0.224 & $\mathrm{TiO}_{2}$ & 0.856 & -0.064 & 0.040 & 0.085 \\
\hline Co & 0.820 & 0.211 & -0.200 & -0.219 & $\mathrm{~V}_{2} \mathrm{O}_{5}$ & 0.449 & -0.041 & 0.467 & 0.417 \\
\hline $\mathrm{Mn}$ & 0.572 & 0.393 & 0.517 & -0.078 & $\mathrm{Cr}_{2} \mathrm{O}_{3}$ & 0.310 & -0.070 & 0.837 & 0.029 \\
\hline $\mathrm{Fe}$ & 0.830 & 0.395 & -0.034 & -0.166 & $\mathrm{MnO}$ & 0.622 & 0.179 & 0.665 & 0.012 \\
\hline As & 0.099 & -0.075 & -0.638 & -0.528 & $\mathrm{Fe}_{2} \mathrm{O}_{3}$ & 0.884 & 0.250 & 0.062 & -0.144 \\
\hline $\mathrm{Cd}$ & -0.249 & 0.551 & -0.567 & 0.351 & LOI & -0.312 & 0.133 & -0.171 & -0.612 \\
\hline $\mathrm{Cr}$ & 0.755 & 0.431 & -0.202 & -0.148 & PH & 0.283 & -0.238 & -0.348 & -0.059 \\
\hline $\mathrm{Na}_{2} \mathrm{O}$ & -0.450 & 0.143 & 0.782 & -0.038 & O.M & 0.250 & 0.558 & -0.359 & 0.198 \\
\hline $\mathrm{MgO}$ & 0.799 & -0.498 & -0.164 & -0.022 & Eigenvalue & 9.428 & 4.821 & 4.221 & 2.264 \\
\hline $\mathrm{Al}_{2} \mathrm{O}_{3}$ & 0.852 & -0.297 & -0.264 & 0.032 & Variability \% & 33.670 & 17.217 & 15.076 & 8.085 \\
\hline $\mathrm{SiO}_{2}$ & 0.840 & -0.187 & 0.250 & 0.274 & Cumulative\% & 33.670 & 50.887 & 65.963 & 74.048 \\
\hline $\mathrm{P}_{2} \mathrm{O}_{5}$ & 0.045 & 0.178 & -0.405 & 0.746 & & & & & \\
\hline
\end{tabular}

Factor 1

There was a positive loading of the elements of nickel, cobalt, manganese, iron, and chromium, (Fig. 4) due to the similarity of their sources which may be mostly natural, iron and manganese have associated geochemically in clay minerals, or may be attributed to military sources which show high loading in the first factor of the sites (S5 and S15) which attacked by military operations (Table 8 ) noted that the anthropogenic metals such as lead, zinc and cadmium appeared with negative loads.

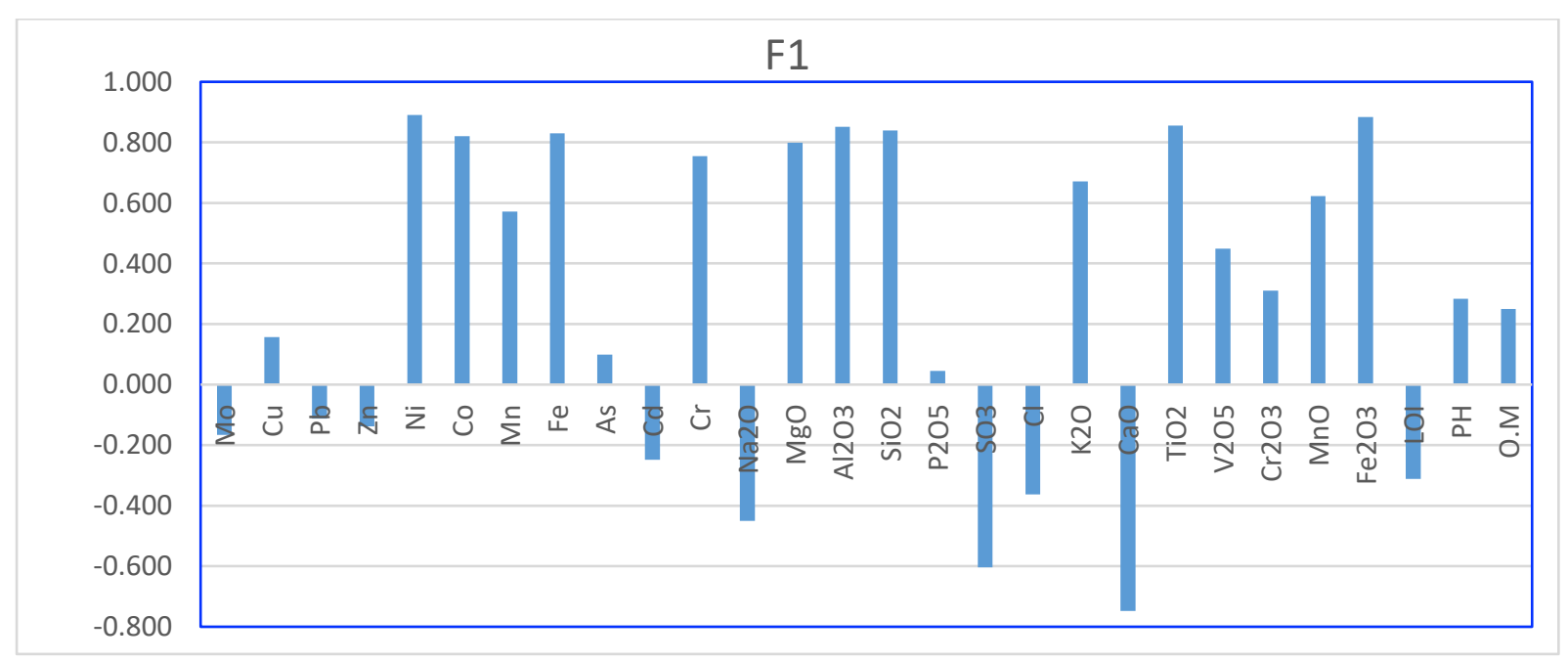

Fig. 4. Loading factor 1 
Table 8. Factor scores

\begin{tabular}{|c|c|c|c|c|c|c|c|c|c|}
\hline Samples & F1 & F2 & F3 & F4 & Samples & F1 & F2 & F3 & F4 \\
\hline S1 & -6.602 & 2.365 & 1.392 & 2.487 & S12 & -2.230 & -1.211 & 1.512 & 0.031 \\
\hline S2 & 3.392 & 5.628 & 1.551 & -1.553 & S13 & 1.927 & -1.693 & 4.286 & -0.439 \\
\hline S3 & -0.457 & -0.186 & -1.314 & 0.138 & S14 & -0.835 & -0.332 & -2.778 & 0.080 \\
\hline S4 & -4.452 & -2.747 & -0.173 & -2.407 & S15 & 4.582 & -0.728 & -1.453 & 1.120 \\
\hline S5 & 5.165 & -1.279 & 3.519 & -0.231 & S16 & -3.984 & -0.714 & 0.685 & -0.461 \\
\hline S6 & 0.588 & -1.151 & -2.351 & -2.046 & S17 & -2.177 & 0.571 & 0.981 & 2.693 \\
\hline S7 & -0.613 & 6.201 & -1.186 & -1.609 & S18 & -0.953 & -0.891 & 1.467 & 1.737 \\
\hline S8 & -0.810 & -0.463 & -1.730 & -1.993 & S19 & -0.468 & -0.116 & 0.849 & 0.138 \\
\hline S9 & 2.182 & 0.116 & 2.021 & -0.419 & S20 & 0.028 & 0.354 & -0.521 & 0.630 \\
\hline S10 & -0.283 & -2.699 & -0.429 & -1.635 & S21 & -0.150 & -0.208 & -3.832 & 1.608 \\
\hline S11 & 6.149 & -0.818 & -2.495 & 2.130 & & & & &
\end{tabular}

Factor 2

The second factor shows positive loads of the elements of molybdenum, copper, lead, zinc, cadmium, and chromium in Table 7) which may indicate the anthropogenic sources such as industrial waste, emissions of vehicles exhaust and oils waste, as these activities are the main sources of heavy metals polluting the environment also that there are no strong positive loads of oxides that represent the main natural components of the soil (Fig. 5) (Table 8), high positive loading of sites S1, S2 and S7 (Fig. 6) represents industrial areas near the grain mill, car wash and repairing garage, respectively, in the study area.

Factor 3

The third factor gives positive loads for manganese, chromium and vanadium oxide as in Table 7) and Fig. 7. This may be due to the use of chromium in industrial activities such as dyes and steel. For manganese, it may be due to the different natural sources of the soil, as manganese is one of the main components of it, there is a high load of the sites S13 and S5 because, the S13 represents a football stadium and its soil was brought from other sites, as for S5 represents the industrial area in the study area.

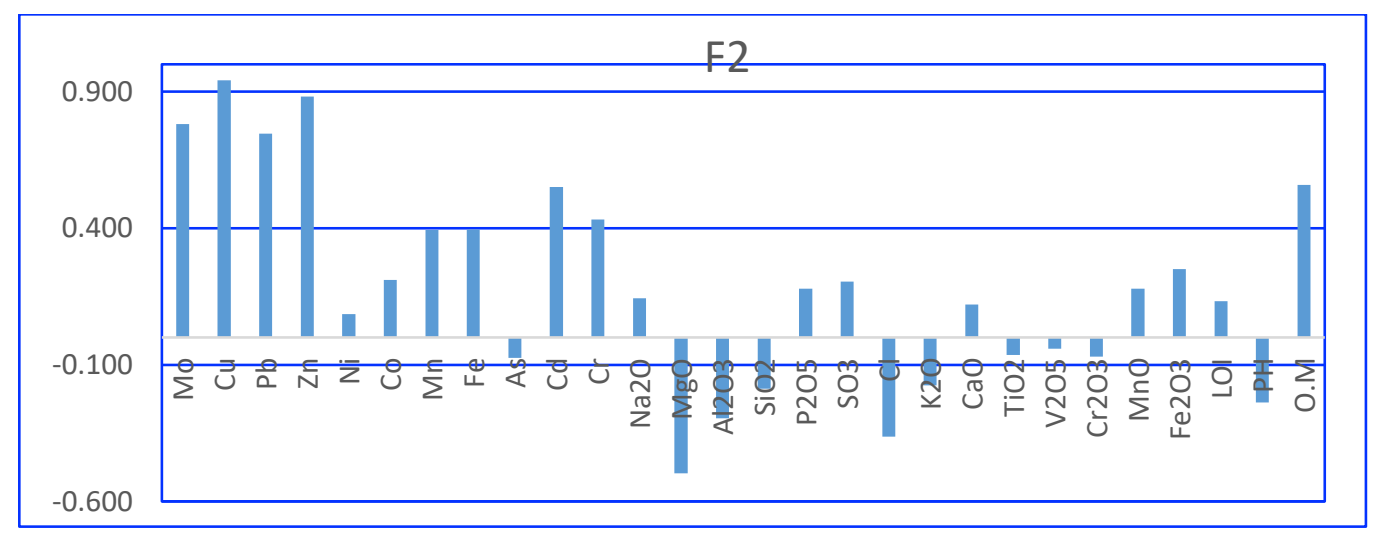

Fig. 5. Loading factor 2 


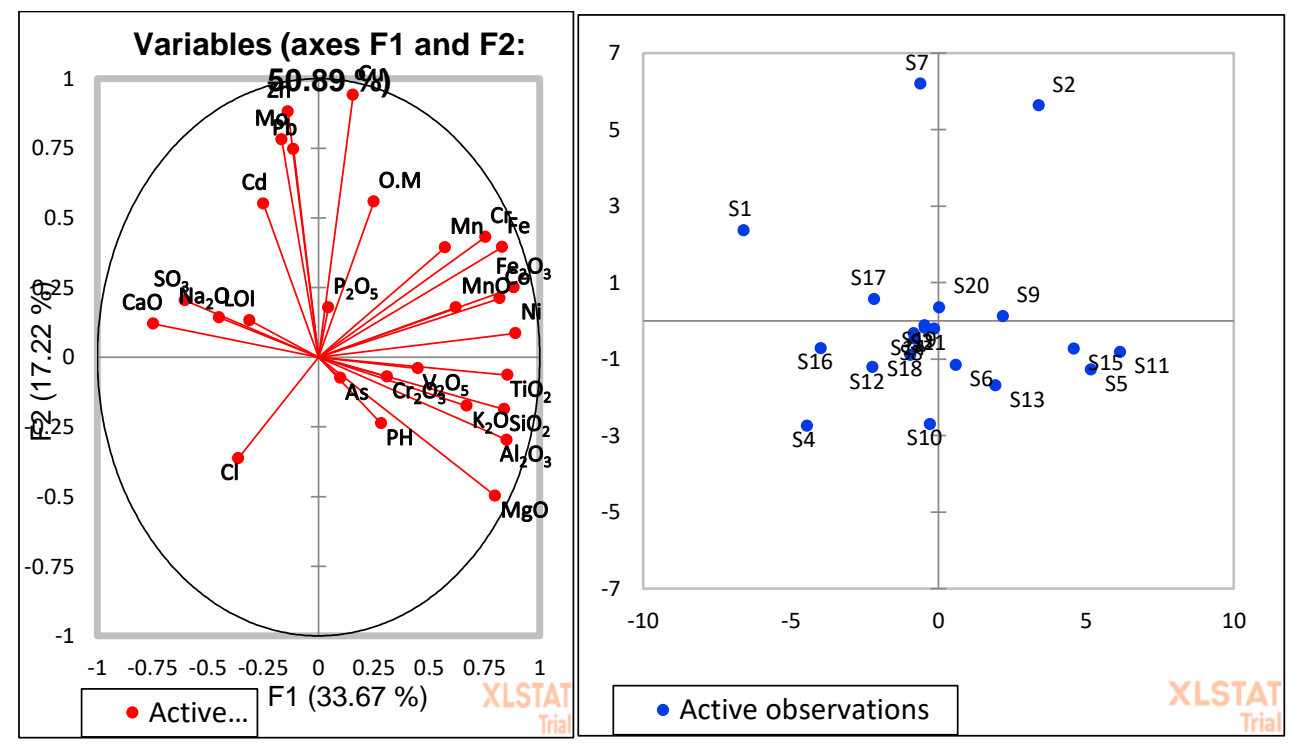

Fig. 6. Biplot F1 and F2

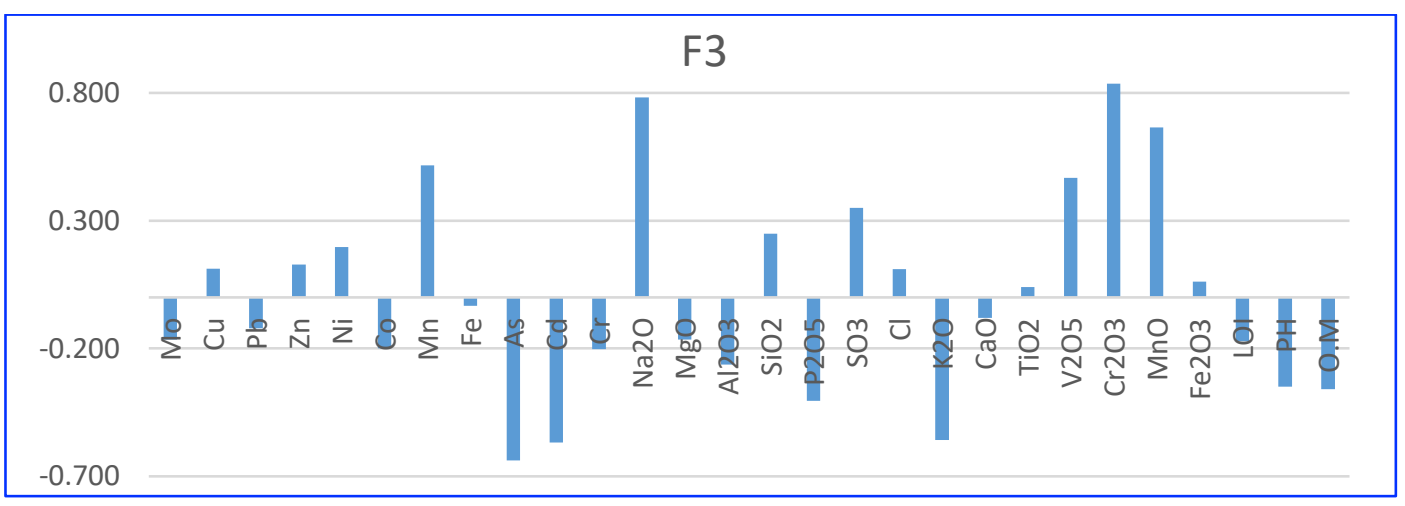

\section{Factor 4}

Fig. 7. Loading factor 3

The fourth factor, positive loading of cadmium and phosphorus oxide is determined (Fig. 8) and it may be due to the anthropogenic source, such as agricultural pesticides and liquid wastes, as there was a high load in the sites (S11 and S21) (Table 8) which represents fruits and vegetables store and small farm, S1 which represents the industrial area, and S17 represents a residential area near the electricity generator in the study area.

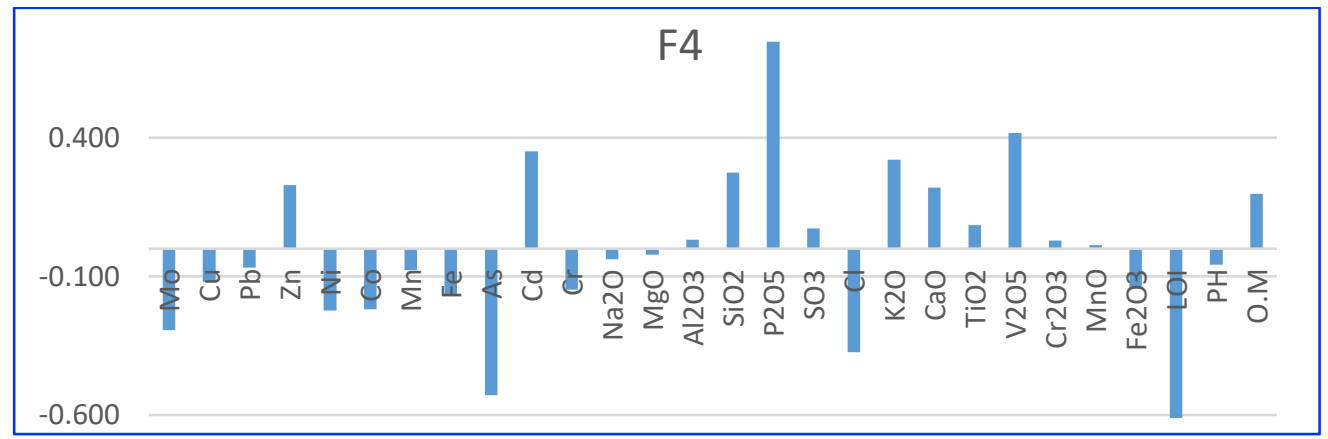

Fig. 8. Loading factor 4 


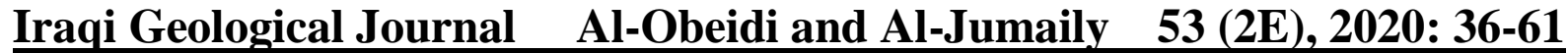

\section{Indices Assessment}

\section{Contamination factor (CF) and degree of Contamination (DoC)}

Through the results of the contamination factor (CF) for the heavy metals studied in the surface soil of Al-Hawija Town, there was a high pollution element with copper in the two sites (S7, S2) and may be due to industrial waste product in this area (Devi and Yadav, 2018) (Table 9). For the lead it was highly polluted at the sites of S1, S2, S3, S7, S17 and S20 this may be due to emissions from heavy traffic (Szwalec et al., 2020), zinc has been recorded as mild pollution at sites S1, S2, S7, S9 and S17 due to industrial and sewage waste product (Liu et al., 2020), for the nickel all sites indicated high pollution and it's reason may be due to the release of large amount of it as a result of human activities, such as car's emissions and domestic waste (Terry and Banuelos, 2000). Cobalt show mild contamination in all locations except (S1, S4, S12) and this may be due to liquid waste product, used in fertilizers phosphate, car's emissions and exhaust vehicles (Leyssens et al., 2017; Suh et al., 2016). Arsenic has recorded moderate pollution in all locations as a result of high traffic density (Sosa-Rodríguez et al., 2020). As for the chromium all sites represent low pollution category, which may be related to industrial uses (Ihedioha et al., 2017). For the elements of molybdenum, iron, and cadmium all sites show no pollution category except in the cadmium at site S21 was from the category of low pollution. By calculating the DoC, the sites (S2 and S7) were within the category of High contamination, this may be due to industrial activities contaminated with heavy metals because sites of S2 and S7 represent industrial areas.

\section{Geoaccumulation index (Igeo)}

There is medium to high pollution with the nickel element in the industrial area, This was attributed to industrial waste product and heavy traffic, for the copper it has the geoaccumulation index for the sites was between class 0 to class 1 (uncontaminated to moderately contaminated) except for the sites S2 and S7 it was class 2 (moderately contaminated) and this is due to industrial waste product in the industrial district, and the lead was in most of the sites within the class 0 and class1 category except for the sites S1, S2 and S3 within the class 2 category, the site S7 within the class 4 category (heavily contaminated) due to the emissions of the gasoline burning as well as industrial waste from solid oils and waste, while the zinc was between class 0 and class 1 , and the nickel in all models of class 2 except for sites S2, S5, S9, S1 1 and S13 were in the class 3 category this may be due to industrial and domestic wastes as well as car's emissions. For the cobalt, arsenic, and chromium, all sites were in class 1 category, and for the molybdenum, manganese, iron and cadmium there were in the class 0 category (Table 10) and (Fig. 9). 
Iraqi Geological Journal Al-Obeidi and Al-Jumaily 53 (2E), 2020: 36-61

Table 9. (CF) and (DoC) values in the top soil of the study area

\begin{tabular}{|c|c|c|c|c|c|c|c|c|c|c|c|c|}
\hline Sample No & $\mathrm{Mo}$ & $\mathrm{Cu}$ & $\mathrm{Pb}$ & $\mathrm{Zn}$ & $\mathrm{Ni}$ & $\mathrm{Co}$ & $\mathrm{Mn}$ & $\mathrm{Fe}$ & $\mathrm{As}$ & $\mathrm{Cd}$ & $\mathrm{Cr}$ & $\mathrm{DoC}$ \\
\hline S1 & 0.64 & 2.78 & 4.56 & 2.93 & 4.30 & 1.66 & 0.80 & 0.64 & 2.32 & 0.92 & 1.44 & 23.0 \\
\hline S2 & 0.79 & 5.30 & 3.29 & 2.97 & 6.19 & 2.36 & 1.16 & 0.92 & 2.68 & 0.66 & 1.80 & 28.1 \\
\hline S3 & 0.43 & 1.74 & 3.55 & 1.72 & 5.50 & 2.06 & 0.81 & 0.73 & 2.68 & 0.78 & 1.58 & 21.6 \\
\hline S4 & 0.34 & 1.16 & 0.54 & 0.74 & 4.82 & 1.81 & 0.78 & 0.65 & 2.68 & 0.48 & 1.42 & 15.4 \\
\hline S5 & 0.39 & 1.92 & 0.98 & 0.88 & 6.58 & 2.26 & 1.02 & 0.79 & 2.48 & 0.36 & 1.70 & 19.4 \\
\hline S6 & 0.44 & 1.39 & 0.64 & 0.92 & 5.52 & 2.19 & 0.88 & 0.75 & 2.92 & 0.62 & 1.66 & 17.9 \\
\hline S7 & 0.86 & 4.52 & 23.20 & 2.78 & 5.66 & 2.24 & 0.99 & 0.74 & 2.64 & 0.92 & 1.73 & 46.3 \\
\hline S8 & 0.59 & 1.36 & 0.65 & 0.86 & 5.42 & 2.20 & 0.85 & 0.71 & 3.00 & 0.56 & 1.65 & 17.9 \\
\hline S9 & 0.26 & 2.19 & 0.89 & 2.16 & 6.22 & 2.20 & 0.98 & 0.76 & 2.48 & 0.52 & 1.67 & 20.3 \\
\hline S10 & 0.34 & 1.31 & 0.62 & 0.82 & 5.57 & 2.08 & 0.91 & 0.69 & 2.76 & 0.54 & 1.48 & 17.1 \\
\hline S11 & 0.31 & 1.71 & 0.81 & 1.11 & 6.11 & 2.34 & 0.93 & 0.82 & 2.56 & 0.64 & 1.73 & 19.1 \\
\hline S12 & 0.46 & 1.54 & 1.23 & 1.28 & 4.70 & 1.95 & 0.99 & 0.63 & 2.44 & 0.54 & 1.32 & 17.1 \\
\hline S13 & 0.22 & 1.31 & 0.54 & 0.76 & 6.05 & 2.19 & 1.00 & 0.72 & 2.40 & 0.32 & 1.61 & 17.1 \\
\hline S14 & 0.47 & 1.63 & 1.86 & 1.08 & 5.28 & 2.20 & 0.83 & 0.71 & 2.92 & 0.62 & 1.65 & 19.2 \\
\hline S15 & 0.42 & 2.03 & 2.75 & 1.29 & 5.72 & 2.19 & 0.93 & 0.78 & 2.68 & 0.64 & 1.72 & 21.2 \\
\hline S16 & 0.48 & 1.40 & 1.24 & 0.97 & 5.18 & 2.11 & 0.84 & 0.65 & 2.52 & 0.48 & 1.49 & 17.4 \\
\hline S17 & 0.33 & 1.94 & 5.20 & 2.13 & 5.01 & 2.00 & 0.93 & 0.65 & 2.48 & 0.72 & 1.50 & 22.9 \\
\hline S18 & 0.29 & 1.42 & 1.14 & 1.30 & 5.35 & 2.01 & 0.99 & 0.69 & 2.48 & 0.54 & 1.48 & 17.7 \\
\hline S19 & 0.26 & 1.63 & 1.87 & 1.23 & 5.43 & 2.03 & 0.98 & 0.74 & 2.44 & 0.58 & 1.66 & 18.8 \\
\hline S20 & 0.25 & 1.65 & 4.58 & 1.61 & 5.72 & 2.15 & 0.88 & 0.73 & 2.28 & 0.54 & 1.64 & 22.0 \\
\hline S21 & 0.38 & 1.56 & 1.63 & 1.30 & 5.20 & 2.20 & 0.86 & 0.71 & 2.68 & 1.04 & 1.61 & 19.2 \\
\hline Average & 0.43 & 1.98 & 2.94 & 1.47 & 5.50 & 2.12 & 0.92 & 0.73 & 2.60 & 0.62 & 1.60 & 20.9 \\
\hline
\end{tabular}

Table 10. Igeo value in the top soil of the study area

\begin{tabular}{|c|c|c|c|c|c|c|c|c|c|c|c|}
\hline Sample No & Mo & $\mathbf{C u}$ & $\mathbf{P b}$ & $\mathbf{Z n}$ & $\mathbf{N i}$ & $\mathbf{C o}$ & $\mathbf{M n}$ & $\mathbf{F e}$ & $\mathbf{A s}$ & $\mathbf{C d}$ & $\mathbf{C r}$ \\
\hline S1 & -1.23 & 0.89 & 1.60 & 0.96 & 1.52 & 0.15 & -0.91 & -1.24 & 0.63 & -0.71 & -0.06 \\
\hline S2 & -0.93 & 1.82 & 1.13 & 0.98 & 2.05 & 0.66 & -0.38 & -0.71 & 0.84 & -1.18 & 0.26 \\
\hline S3 & -1.81 & 0.22 & 1.24 & 0.20 & 1.87 & 0.46 & -0.89 & -1.03 & 0.84 & -0.94 & 0.07 \\
\hline S4 & -2.12 & -0.37 & -1.48 & -1.02 & 1.68 & 0.27 & -0.94 & -1.20 & 0.84 & -1.64 & -0.08 \\
\hline S5 & -1.95 & 0.35 & -0.62 & -0.77 & 2.13 & 0.59 & -0.56 & -0.92 & 0.73 & -2.06 & 0.18 \\
\hline S6 & -1.75 & -0.11 & -1.23 & -0.71 & 1.88 & 0.54 & -0.77 & -1.00 & 0.96 & -1.27 & 0.15 \\
\hline S7 & -0.80 & 1.59 & 3.95 & 0.89 & 1.92 & 0.58 & -0.60 & -1.02 & 0.82 & -0.71 & 0.21 \\
\hline S8 & -1.35 & -0.14 & -1.20 & -0.81 & 1.85 & 0.55 & -0.82 & -1.07 & 1.00 & -1.42 & 0.14 \\
\hline S9 & -2.52 & 0.55 & -0.75 & 0.53 & 2.05 & 0.55 & -0.62 & -0.98 & 0.73 & -1.53 & 0.16 \\
\hline S10 & -2.15 & -0.20 & -1.27 & -0.87 & 1.89 & 0.47 & -0.72 & -1.12 & 0.88 & -1.47 & -0.02 \\
\hline S11 & -2.27 & 0.19 & -0.89 & -0.44 & 2.03 & 0.64 & -0.68 & -0.87 & 0.77 & -1.23 & 0.20 \\
\hline S12 & -1.70 & 0.04 & -0.29 & -0.22 & 1.65 & 0.38 & -0.59 & -1.24 & 0.70 & -1.47 & -0.18 \\
\hline S13 & -2.79 & -0.19 & -1.48 & -0.98 & 2.01 & 0.54 & -0.58 & -1.06 & 0.68 & -2.23 & 0.11 \\
\hline S14 & -1.67 & 0.12 & 0.31 & -0.47 & 1.82 & 0.55 & -0.86 & -1.09 & 0.96 & -1.27 & 0.14 \\
\hline S15 & -1.83 & 0.43 & 0.87 & -0.21 & 1.93 & 0.54 & -0.70 & -0.94 & 0.84 & -1.23 & 0.20 \\
\hline S16 & -1.63 & -0.10 & -0.27 & -0.63 & 1.79 & 0.49 & -0.84 & -1.20 & 0.75 & -1.64 & -0.01 \\
\hline S17 & -2.17 & 0.37 & 1.79 & 0.51 & 1.74 & 0.42 & -0.70 & -1.20 & 0.73 & -1.06 & 0.00 \\
\hline S18 & -2.35 & -0.08 & -0.40 & -0.20 & 1.83 & 0.42 & -0.60 & -1.13 & 0.73 & -1.47 & -0.02 \\
\hline S19 & -2.52 & 0.12 & 0.32 & -0.29 & 1.86 & 0.43 & -0.61 & -1.01 & 0.70 & -1.37 & 0.15 \\
\hline S20 & -2.58 & 0.14 & 1.61 & 0.10 & 1.93 & 0.52 & -0.77 & -1.03 & 0.60 & -1.47 & 0.13 \\
\hline S21 & -1.99 & 0.06 & 0.12 & -0.20 & 1.79 & 0.55 & -0.81 & -1.07 & 0.84 & -0.53 & 0.10 \\
\hline Average & -1.91 & 0.27 & 0.15 & -0.17 & 1.87 & 0.49 & -0.71 & -1.05 & 0.79 & -1.33 & 0.09 \\
\hline
\end{tabular}




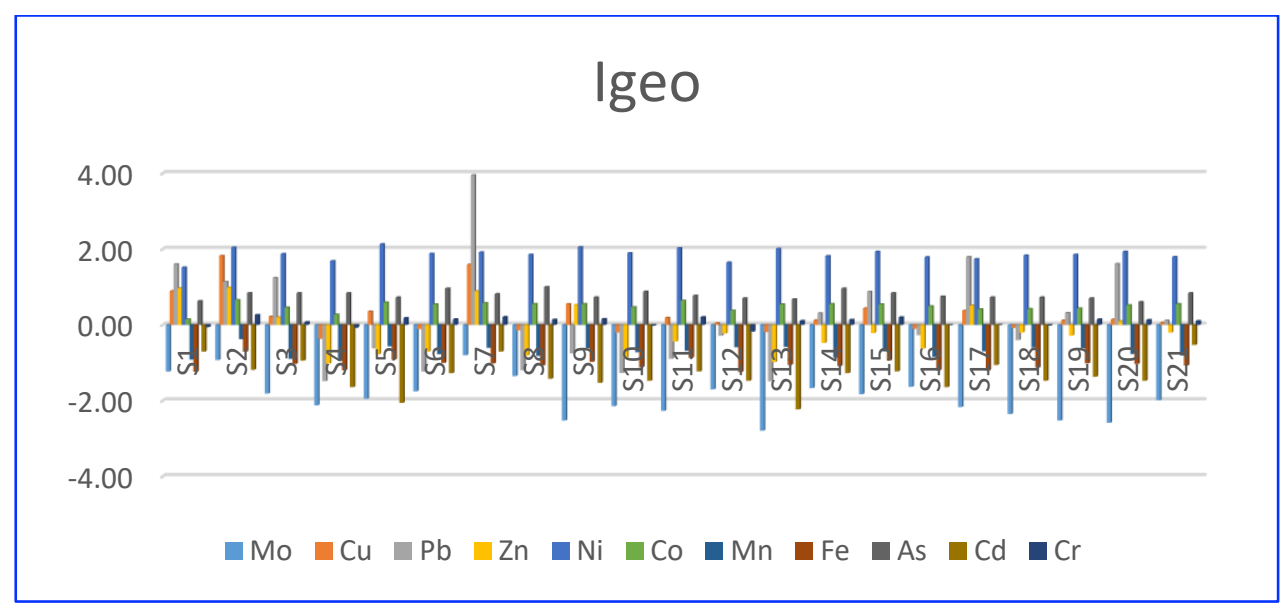

Fig. 9. Geoaccumulation index in surface soil of Al-Hawija area

\section{Pollution load index (PLI)}

The average pollution load index in the surface soil of Al-Hawija town is 1.4 (Table 11) which indicates that all sites were higher than 1(polluted according to the load index classification), as it was the highest pollution in the site S7 was 2.3 this may be due to the high pollution of the lead in the southeast of the town which represented the industrial area (Fig. 10).

Table 11. Pollution load index (PLI) value

\begin{tabular}{|c|c|c|c|}
\hline Sample No & PLI & Sample No & PLI \\
\hline S1 & 1.7 & S12 & 1.2 \\
\hline S2 & 2.0 & S13 & 1.0 \\
\hline S3 & 1.5 & S14 & 1.4 \\
\hline S4 5 & 1.0 & S15 & 1.5 \\
\hline S6 & 1.3 & S16 & 1.2 \\
\hline S7 & 1.2 & S17 & 1.5 \\
\hline S8 & 2.3 & S18 & 1.2 \\
\hline S9 & 1.2 & S19 & 1.3 \\
\hline S10 & 1.3 & S20 & 1.4 \\
\hline S11 & 1.1 & S21 & 1.4 \\
\hline
\end{tabular}
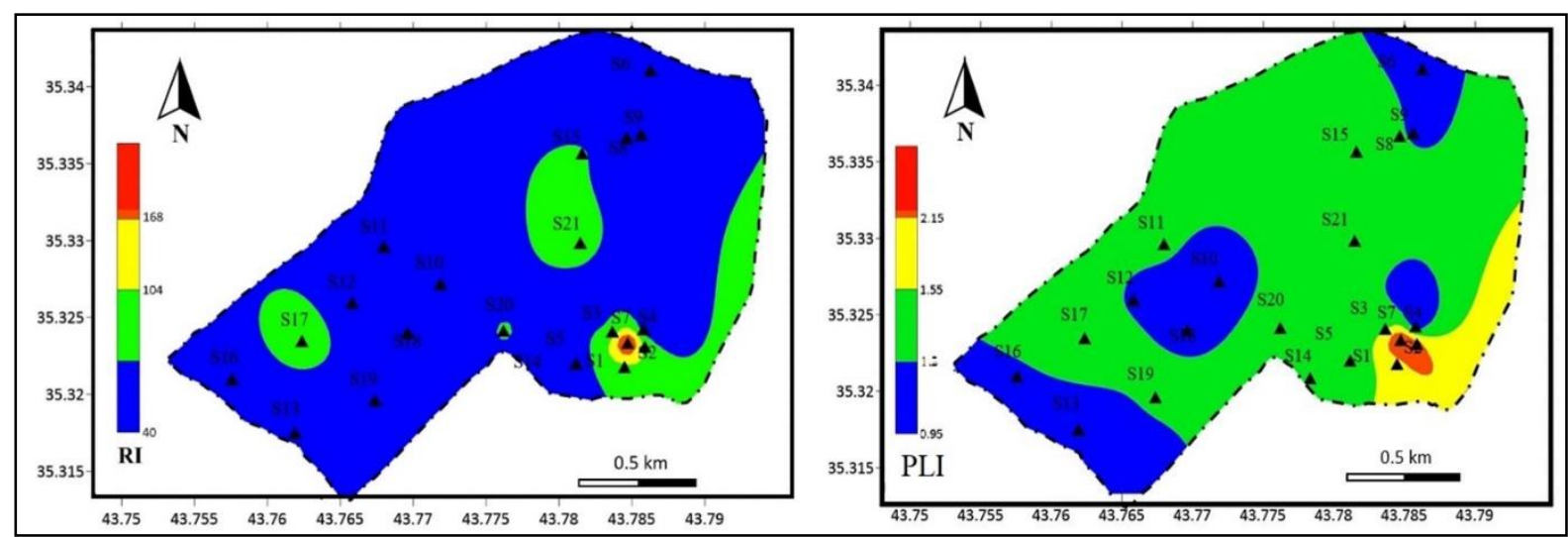

Fig. 10. Spatial distribution of risk index (RI) and pollution load index (PLI) in the top soil of Al-Hawija area 


\section{Potential ecological risk index (RI)}

The ecological risk index for the studied heavy metals was calculated and Er value of the elements ( $\mathrm{Cr} \mathrm{Cu}, \mathrm{Pb}, \mathrm{As}, \mathrm{Cd})$ was less than 40 except for the lead element in the site $\mathrm{S} 7$ where Er value was 116 which represent considerable potential ecological risk, and the environmental risk quotient index was calculated for the following elements $(\mathrm{Cr} \mathrm{Cu}, \mathrm{Pb}, \mathrm{As}, \mathrm{Cd}$,) (Table 12) and (Fig. 10) and it was found that all sites were less than 150 (under the Low category Ecological Risk) except for the site S7 was in the category of moderate ecological risk, This may be due to the high ecological risk index with lead, copper and arsenic in that site.

Table 12. The (Er) and (RI) value for some heavy metals in the soil of the study area

\begin{tabular}{|c|c|c|c|c|c|c|c|c|c|c|c|c|c|}
\hline Sample & $\mathbf{C u}$ & $\mathbf{P b}$ & As & $\mathbf{C d}$ & $\mathbf{C r}$ & $\mathbf{R I}$ & Sample & $\mathbf{C u}$ & $\mathbf{P b}$ & $\mathbf{A s}$ & $\mathbf{C d}$ & $\mathbf{C r}$ & $\mathbf{R I}$ \\
\hline S1 & 13.9 & 22.8 & 23.2 & 27.6 & 2.9 & 90.4 & S12 & 7.7 & 6.2 & 24.4 & 16.2 & 2.6 & 57.1 \\
\hline S2 & 26.5 & 16.5 & 26.8 & 19.8 & 3.6 & 93.1 & S13 & 6.6 & 2.7 & 24.0 & 9.6 & 3.2 & 46.1 \\
\hline S3 & 8.7 & 17.7 & 26.8 & 23.4 & 3.2 & 79.8 & S14 & 8.2 & 9.3 & 29.2 & 18.6 & 3.3 & 68.5 \\
\hline S4 & 5.8 & 2.7 & 26.8 & 14.4 & 2.8 & 52.5 & S15 & 10.1 & 13.7 & 26.8 & 19.2 & 3.4 & 73.3 \\
\hline S5 & 9.6 & 4.9 & 24.8 & 10.8 & 3.4 & 53.5 & S16 & 7.0 & 6.2 & 25.2 & 14.4 & 3.0 & 55.8 \\
\hline S6 & 7.0 & 3.2 & 29.2 & 18.6 & 3.3 & 61.3 & S17 & 9.7 & 26.0 & 24.8 & 21.6 & 3.0 & 85.1 \\
\hline S7 & 22.6 & 116 & 26.4 & 27.6 & 3.5 & 196.1 & S18 & 7.1 & 5.7 & 24.8 & 16.2 & 3.0 & 56.7 \\
\hline S8 & 6.8 & 3.3 & 30.0 & 16.8 & 3.3 & 60.2 & S19 & 8.1 & 9.3 & 24.4 & 17.4 & 3.3 & 62.6 \\
\hline S9 & 11.0 & 4.5 & 24.8 & 15.6 & 3.3 & 59.2 & S20 & 8.3 & 22.9 & 22.8 & 16.2 & 3.3 & 73.5 \\
\hline S10 & 6.5 & 3.1 & 27.6 & 16.2 & 3.0 & 56.4 & S21 & 7.8 & 8.1 & 26.8 & 31.2 & 3.2 & 77.2 \\
\hline S11 & 8.5 & 4.0 & 25.6 & 19.2 & 3.5 & 60.8 & Average & 9.9 & 14.7 & 26.0 & 18.6 & 3.2 & 72.3 \\
\hline
\end{tabular}

\section{CONCLUSIONS}

1- The results of heavy metal concentrations in the surface soil show a significant increase in lead, chromium, copper and zinc concentrations in industrial areas due to anthropogenic sources

2- Through the spatial distribution maps of heavy metals, it was found that copper, lead, chromium, molybdenum, zinc, cadmium and iron had increased in industrial areas more than commercial and residential areas as a result of industrial waste product and heavy traffic, while for the nickel, cobalt, manganese and arsenic they increased in commercial areas as a result of anthropogenic waste and agricultural activities and military operations.

3- An analysis of the size fraction of the soil showed that all studied heavy metals increased in the fine parts (clay) as a result of the presence of iron and manganese oxides and clay minerals adsorption and absorption.

4- The correlation coefficient showed that there is a positive correlation between the molybdenum, copper, lead, zinc and cadmium which indicated their participation in anthropogenic sources. 
5- The factor analysis of the heavy metals in the soil showed that $17.21 \%$ of the total variation of the elements was the result of anthropogenic activities in the region and that the greatest was in the industrial areas in the town.

6- Indices assessment showed high pollution of the lead element in the site $\mathrm{S} 7(\mathrm{CF}=23.20)$ and $(\operatorname{Igeo}=3.95)$ as a result of industrial waste product, also a high ecological risk in the same site.

\section{ACKNOWLEDGMENTS}

The authors would like to thank Dr. Anmar E. Rafik for linguistic assistance in this paper. The authors are very grateful to the Editor in Chief Prof. Dr. Salih M. Awadh, the Secretary of Journal Mr. Samir R. Hijab and the Technical Editor Dr. Heba S. Al-Mimar for their great efforts and valuable comments.

\section{REFERENCES}

Addy, M., Losey, B., Mohseni, R., Zlotnikov, E., and Vasiliev, A., 2012. Adsorption of heavy metal ions on mesoporous silica-modified montmorillonite containing a grafted chelate ligand: Applied Clay Science, 59: $115-120$.

Adriano, D., 2001. Biogeochemistry, bioavailability and risks of metals: Trace elements in the terrestrial environment:(2nd Edition), Springer-Verlag, New York, NY, USA.

Akpomie, K. G., and Dawodu, F. A., 2016. Acid-modified montmorillonite for sorption of heavy metals from automobile effluent: Beni-uef University. Journal of Basic and Applied Sciences, 5(1): 1-12. https://doi.org/10.1016/j.bjbas.2016.01.003

Al-Anbari, R., Al Obaidy, A., and Ali, F., 2015. Pollution loads and ecological risk assessment of heavy metals in the urban soil affected by various anthropogenic activities: International Journal of Advanced Research, 3(2): 104-110.

Al-Hamdani, J. A. J., Awadh, S. M., and Ibrahim, O. S., 2016. Geochemical partitioning of heavy metals in the urban soil, Kirkuk, Iraq: Iraqi Geological Journal, 39-49(1): 1-24.

Al-Jaberi, M. H., Al-Dabbas, M. A., and Al-Khafaji, R., 2016. Assessment of heavy metals contamination and sediment quality in Shatt Al-Arab river S Iraq: Iraqi Geological Journal, 39-49 (1): 88-97.

Al-Jumaily, H. A. A., and Rasheed, B. R., 2018. The Geochemical distribution and assessment of heavy metals pollutions in soil sediment of Chamchamal City-Sulaimanya Governorate, NortherEastern Iraq, Journal of Environment and Earth Science, 113-147.

Al-jumaly, H. A. A., 2007. Heavy metals concentrations in surface soils of the Haweja area south western of Kirkuk, Iraq: Kirkuk University Journal for Scientific Studies, 2(3): 35-48.

Al-Khashman, O. A., 2007. The investigation of metal concentrations in street dust samples in Aqaba city, Jordan: Environmental Geochemistry and Health, 29 (3):197-207.

Albanese, S., Sadeghi, M., Lima, A., Cicchella, D., Dinelli, E., Valera, P., Falconi, M., Demetriades, A., De Vivo, B., and Team, T. G. P., 2015. GEMAS: cobalt, $\mathrm{Cr}, \mathrm{Cu}$ and $\mathrm{Ni}$ distribution in agricultural and grazing land soil of Europe: Journal of Geochemical Exploration, 154: 81-93. https://doi.org/10.1016/j.gexplo.2015.01.004

Ali, H., and Khan, E., 2018. What are heavy metals? Long-standing controversy over the scientific use of the term 'heavy metals' - proposal of a comprehensive definition: Toxicological and Environmental Chemistry, 100 (1): 6-19.

Argyraki, A., Boutsi, Z., and Zotiadis, V., 2017. Towards sustainable remediation of contaminated soil by using diasporic bauxite: Laboratory experiments on soil from the sulfide mining village of Stratoni, Greece: Journal of Geochemical Exploration, 183: 214-222. 
Awadh, S. M., and Al-Hamdani, J. A., 2019. Urban geochemistry assessment using pollution indices: a case study of urban soil in Kirkuk, Iraq: Environmental Earth Sciences, 78 (20): 587. https://link.springer.com/article/10.1007\%2Fs12665-019-8615-3

Awadh, S. M., Al-Kilabi, J. A., and Khaleefah, N. H., 2015. Comparison the geochemical background, threshold and anomaly with pollution indices in the assessment of soil pollution: Al-Hawija, North of Iraq case study, International Journal of Science Resources (IJSR), 4 (7): 2357-2363.

Awadh, S. M., and Yousif, A. A. H., 2015. Sorption efficiency of kaolinte in removal Cd from aqueous solutions: Iraqi Journal of Science, 56 (2C): 1699-1707.

Awadh. S., M., 2015. Cd, Ni, and Pb distribution and pollution assessment in roadside dust from Baghdad City and Western Iraqi Desert. Arabian J. of Geosciences, 8:315-323, DOI 10.1007/s12517-013-1204-y.

Bhattacharyya, K. G., and Gupta, S. S., 2008. Adsorption of a few heavy metals on natural and modified kaolinite and montmorillonite: a review: Advances in colloid and interface science, 140 (2):114-131.

Bjerrum, N., 1936. Bjerrum's Inorganic Chemistry, 3rd Danish ed, Heinemann, London.

Buringh, P., 1960. Soils and soil conditions in Iraq, Ministry of agriculture.

Carver, R., 1971. Procedures in Sedimentary Petrology. John Willey \& Sons: Inc. Nueva York, 653.

de Miguel, E., Llamas, J. F., Chacón, E., Berg, T., Larssen, S., Røyset, O., and Vadset, M., 1997. Origin and patterns of distribution of trace elements in street dust: unleaded petrol and urban lead: Atmospheric Environment, 31 (17): 2733-2740.

Devi, N. L., and Yadav, I. C., 2018. Chemometric evaluation of heavy metal pollutions in Patna region of the Ganges alluvial plain, India: implication for source apportionment and health risk assessment: Environmental Geochemistry and Health, 40 (6): 2343-2358.

Di Giuseppe, D., Vittori Antisari, L., Ferronato, C., and Bianchini, G., 2014. New insights on mobility and bioavailability of heavy metals in soils of the Padanian alluvial plain (Ferrara Province, northern Italy): Geochemistry, 74 (4): 615-623.

Dvorak, P., Roy, K., Andreji, J., Liskova, Z. D., and Mraz, J., 2020. Vulnerability assessment of wild fish population to heavy metals in military training area: Synthesis of a framework with example from Czech Republic: Ecological Indicators, 110:105920.

El Adraa, K., Georgelin, T., Lambert, J.-F., Jaber, F., Tielens, F., and Jaber, M., 2017. Cysteine-montmorillonite composites for heavy metal cation complexation: A combined experimental and theoretical study: Chemical Engineering Journal, 314: 406-417.

Ertani, A., Mietto, A., Borin, M., and Nardi, S., 2017. Chromium in agricultural soils and crops: A review: Water, Air, \& Soil Pollution, 228:5.

García-Lestón, J., Roma-Torres, J., Vilares, M., Pinto, R., Prista, J., Teixeira, J. P., Mayan, O., Conde, J., Pingarilho, M., and Gaspar, J. F., 2012. Genotoxic effects of occupational exposure to lead and influence of polymorphisms in genes involved in lead toxicokinetics and in DNA repair: Environment international, 43: $29-36$.

Gitari, W., 2014. Attenuation of metal species in acidic solutions using bentonite clay: implications for acid mine drainage remediation: Toxicological \& Environmental Chemistry, 96 (2): 201-217.

Gong, C., Ma, L., Cheng, H., Liu, Y., Xu, D., Li, B., Liu, F., Ren, Y., Liu, Z., and Zhao, C., 2014. Characterization of the particle size fraction associated heavy metals in tropical arable soils from Hainan Island, China: Journal of Geochemical Exploration, 139:109-114. https://doi.org/10.1016/j.gexplo.2013.01.002

Guan, Y., Shao, C., and Ju, M., 2014. Heavy metal contamination assessment and partition for industrial and mining gathering areas: International Journal of Environmental Research and Public Health, 11 (7): 72867303.

Guo, H., Yang, L., Han, X., Dai, J., Pang, X., Ren, M., and Zhang, W., 2019. Distribution characteristics of heavy metals in surface soils from the western area of Nansi Lake, China: 191 (5): 262.

Hakanson, L., 1980. An ecological risk index for aquatic pollution control. A sedimentological approach: Water research, 14 (8): 975-1001. https://doi.org/10.1016/0043-1354(80)90143-8

Hanfi, M. Y., Mostafa, M. Y. A., and Zhukovsky, M. V., 2019. Heavy metal contamination in urban surface sediments: sources, distribution, contamination control, and remediation, 192 (1): 32.

Idzelis, R. L., Greičiūte, K., and Paliulis, D., 2006. Investigation and evaluation of surface water pollution with heavy metals and oil products in Kairiai military ground territory: Journal of Environmental Engineering and Landscape Management, 14 (4):183-190 
Ihedioha, J., Ukoha, P., and Ekere, N., 2017. Ecological and human health risk assessment of heavy metal contamination in soil of a municipal solid waste dump in Uyo, Nigeria: Environmental Geochemistry and Health, 39 (3): 497-515. https://doi.org/10.1007/s10653-016-9830-4

Inengite, A., Abasi, C., and Walter, C., 2015. Application of pollution indices for the assessment of heavy metal pollution in flood impacted soil: International Research Journal of Pure and Applied Chemistry, 175-189.

Islam, M. N., Nguyen, X. P., Jung, H. Y., and Park, J. H., 2016. Chemical Speciation and quantitative evaluation of heavy metal pollution hazards in two army shooting range backstop soils: Bull Environ Contam Toxicol, 96 (2): 179-185. https://doi.org/10.1007/s00128-015-1689-z

Jaradat, Q. M., and Momani, K. A., 1999. Contamination of roadside soil, plants, and air with heavy metals in Jordan, a comparative study: Turkish Journal of Chemistry, 23 (2): 209-220.

Jassim, S., and Goff, J., 2006. Phanerozoic development of the northern Arabian Plate: Geology of Iraq. Dolin, Prague and Moravian Museum, Brno, 32-44.

Jeldres, R. I., Arancibia-Bravo, M. P., Reyes, A., Aguirre, C. E., Cortes, L., and Cisternas, L. A., 2017. The impact of seawater with calcium and magnesium removal for the flotation of copper-molybdenum sulphide ores: Minerals Engineering, 109:10-13.

Jin, X., Zha, S., Li, S., and Chen, Z., 2014. Simultaneous removal of mixed contaminants by organoclaysamoxicillin and $\mathrm{Cu}$ (II) from aqueous solution: Applied Clay Science, 102:196-201.

Jónsson, J. Ö. G., Davíðsdóttir, B., Jónsdóttir, E. M., Kristinsdóttir, S. M., and Ragnarsdóttir, K. V., 2016. Soil indicators for sustainable development: A transdisciplinary approach for indicator development using expert stakeholders: Agriculture, ecosystems and environment, 232: 179-189.

Kabadayi, F., and Cesur, H., 2010. Determination of $\mathrm{Cu}, \mathrm{Pb}, \mathrm{Zn}, \mathrm{Ni}, \mathrm{Co}, \mathrm{Cd}$, and $\mathrm{Mn}$ in road dusts of Samsun City: Environ Monit Assess, 168 (1-4): 241-253.

Kabata-Pendias, A., 1993. Behavioural properties of trace metals in soils: Applied Geochemistry, 8: 3-9.

Kabata-Pendias, A., and Mukherjee, A. B., 2007. Trace elements from soil to human, Springer Science \& Business Media.

Karbassi, A., and Amirnezhad, R., 2004. Geochemistry of heavy metals and sedimentation rate in a bay adjacent to the Caspian Sea: International Journal of Environmental Science \& Technology, 1 (3):191-198.

Kowalska, J. B., Mazurek, R., Gąsiorek, M., and Zaleski, T., 2018. Pollution indices as useful tools for the comprehensive evaluation of the degree of soil contamination-A review: Environmental Geochemistry and Health, 40 (6): 2395-2420.

Lee, C. S., Li, X.-D., Zhang, G., Li, J., Ding, A.-J., and Wang, T., 2007. Heavy metals and Pb isotopic composition of aerosols in urban and suburban areas of Hong Kong and Guangzhou, South China-evidence of the long-range transport of air contaminants: Atmospheric Environment, 41 (2): 432-447.

Lee, P.-K., Yu, Y.-H., Yun, S.-T., and Mayer, B., 2005. Metal contamination and solid phase partitioning of metals in urban roadside sediments: Chemosphere, 60 (5): 672-689.

Leyssens, L., Vinck, B., Van Der Straeten, C., Wuyts, F., and Maes, L., 2017. Cobalt toxicity in humans-A review of the potential sources and systemic health effects: Toxicology, 387: 43-56.

Liang, J., Feng, C., Zeng, G., Gao, X., Zhong, M., Li, X., Li, X., He, X., and Fang, Y., 2017. Spatial distribution and source identification of heavy metals in surface soils in a typical coal mine city, Lianyuan, China: Environmental Pollution, 225: 681-690.

Liu, G., Wang, J., Liu, X., Liu, X., Li, X., Ren, Y., Wang, J., and Dong, L., 2018. Partitioning and geochemical fractions of heavy metals from geogenic and anthropogenic sources in various soil particle size fractions: Geoderma, 312: 104-113.

Liu, K., Li, C., Tang, S., Shang, G., Yu, F., and Li, Y., 2020. Heavy metal concentration, potential ecological risk assessment and enzyme activity in soils affected by a lead-zinc tailing spill in Guangxi, China: Chemosphere, 126415.

Lohani, M. B., Singh, A., Rupainwar, D., and Dhar, D., 2008. Seasonal variations of heavy metal contamination in river Gomti of Lucknow city region: Environmental monitoring and assessment, 147(1-3): 253-263.

Masindi, V., and Muedi, K. L., 2018. Environmental Contamination by Heavy Metals.

Men, C., Liu, R., Xu, F., Wang, Q., Guo, L., and Shen, Z., 2018. Pollution characteristics, risk assessment, and source apportionment of heavy metals in road dust in Beijing, China: Society Total Environment, 612: 138-147.

Ministry of Municipalities and Public Works, I., 2014: Population of Iraq. 
Mishra, S., and Bharagava, R. N., 2016. Toxic and genotoxic effects of hexavalent chromium in environment and its bioremediation strategies: Journal of Environmental Science and Health, Part C, 34 (1):1-32.

Mohammed, I. J., and Al-Mashaikie, S. Z., 2018. Origin and distribution of clay minerals in the mudstones of the Kolosh Formation in Rawandoz Area, Northeastern Iraq: Iraqi Geological Journal, 51 (2): 75-90.

Muller, G., 1969. Index of geoaccumulation in sediments of the Rhine River: Geology Journal, 2: 108-118.

Nannoni, F., Protano, G., and Riccobono, F., 2011. Fractionation and geochemical mobility of heavy elements in soils of a mining area in northern Kosovo: Geoderma, 161 (1-2): 63-73.

Othman, S. M., Sarsam, S. I., and Ismail, S. A., 2020. Gypsum and limestone dissolution within Fatha Formation (Middle Miocene) at various ph solutions: a laboratory study: Iraqi Geological Journal, 53 (2B): 71-88.

Pietrzykowski, M., Socha, J., and van Doorn, N. S., 2014. Linking heavy metal bioavailability $(\mathrm{Cd}, \mathrm{Cu}, \mathrm{Zn}$ and $\mathrm{Pb}$ ) in Scots pine needles to soil properties in reclaimed mine areas: Society of Total Environment, 470471: 501-510.

Rajaganapathy, V., Xavier, F., Sreekumar, D., and Mandal, P., 2011. Heavy metal contamination in soil, water and fodder and their presence in livestock and products: a review: Journal of Environmental Science and Technology, 4 (3): 234-249.

Rathor, G., Chopra, N., and Adhikari, T., 2014. Nickel as a pollutant and its management: International Resource of Journal Environment Science, 3 (10): 94-98.

Rinklebe, J., Shaheen, S. M., Schröter, F., and Rennert, T., 2016, Exploiting biogeochemical and spectroscopic techniques to assess the geochemical distribution and release dynamics of chromium and lead in a contaminated floodplain soil: Chemosphere, 150: 390-397.

Saeedi, M., Hosseinzadeh, M., Jamshidi, A., and Pajooheshfar, S., 2009. Assessment of heavy metals contamination and leaching characteristics in highway side soils, Iran: Environmental Monitoring and Assessment, 151(1-4): 231-241. https://doi.org/10.1007/s10661-008-0264-z

Shaheen, S. M., and Rinklebe, J., 2014, Geochemical fractions of chromium, copper, and zinc and their vertical distribution in floodplain soil profiles along the Central Elbe River, Germany: Geoderma, 228: 142-159. https://doi.org/10.1016/j.geoderma.2013.10.012

Shawabkeh, R. A., Al-Khashman, O. A., Al-Omari, H. S., and Shawabkeh, A. F., 2007. Cobalt and zinc removal from aqueous solution by chemically treated bentonite: The Environmentalist, 27 (3): 357-363.

Sherene, T., 2010. Mobility and transport of heavy metals in polluted soil environment, in Proceedings Biological forum an International, 2: 112-121.

Sosa-Rodríguez, F. S., Vazquez-Arenas, J., Peña, P. P., Escobedo-Bretado, M. A., Castellanos-Juárez, F. X., Labastida, I., and Lara, R. H., 2020. Spatial distribution, mobility and potential health risks of arsenic and lead concentrations in semiarid fine top-soils of Durango City, Mexico: Catena, 190: 104540. https://doi.org/10.1016/j.catena.2020.104540

$\mathrm{Su}, \mathrm{C} ., 2014$. A review on heavy metal contamination in the soil worldwide: Situation, impact and remediation techniques: Environmental Skeptics and Critics, 3 (2):24.

Suh, M., Thompson, C. M., Brorby, G. P., Mittal, L., and Proctor, D. M., 2016. Inhalation cancer risk assessment of cobalt metal: Regul Toxicol Pharmacol, 79: 74-82.

Sun, L., Carey, M., Yang, L., Chen, L.-D., Li, S.-J., Zhao, F.-K., Zhu, Y.-G., Meharg, C., and Meharg, A. A., 2018. Source identification of trace elements in Peri-urban soils in Eastern China: Exposure and Health, 11 (3): 195-207.

Szwalec, A., Mundała, P., Kędzior, R., and Pawlik, J., 2020. Monitoring and assessment of cadmium, lead, zinc and copper concentrations in arable roadside soils in terms of different traffic conditions: Environmental Monitoring and Assessment, 192 (3): 155.

Taghavi, S. N., Kamani, H., Dehghani, M. H., Nabizadeh, R., Afshari, N., and Mahvi, A. H., 2019. Assessment of heavy metals in street dusts of Tehran using enrichment factor and geo-accumulation index: Health Scope, $8(1): 9$.

Tang, Q., Li, Y., and Xu, Y., 2015. Land suitability assessment for post-earthquake reconstruction: A case study of Lushan in Sichuan, China: Journal of Geographical Sciences, 25 (7): 865-878. https://doi.org/10.1007/s11442-015-1207-6

Terry, N., and Banuelos, G., 2000. Phytoremediation of contaminated soil and water, CRC Press.

Thornton, I., 1996. Sources and pathways of arsenic in the geochemical environment: health implications: Geological Society, London, Special Publications, 113 (1): 153-161. 
Thorpe, A., and Harrison, R. M., 2008, Sources and properties of non-exhaust particulate matter from road traffic: a review: Society Total Environment, 400 (1-3): 270-282.

Tomlinson, D., Wilson, J., Harris, C., and Jeffrey, D., 1980. Problems in the assessment of heavy-metal levels in estuaries and the formation of a pollution index: Helgoländer meeresuntersuchungen, 33 (1): 566-575.

Vasarevičius, S., and Greičiūte, K., 2004, Investigation of soil pollution with heavy metals in Lithuanian military grounds: Journal of Environmental Engineering and Landscape Management, 12 (4): 132-137

Wang, Y., Hu, J., Xiong, K., Huang, X., and Duan, S., 2012. Distribution of heavy metals in core sediments from Baihua Lake: Procedia Environmental Sciences, 16: 51-58.

Wang, Y., Shi, J., Wang, H., Lin, Q., Chen, X., and Chen, Y., 2007. The influence of soil heavy metals pollution on soil microbial biomass, enzyme activity, and community composition near a copper smelter: Ecotoxicology and environmental safety, 67 (1): 75-81. https://doi.org/10.1016/j.ecoenv.2006.03.007

Wedepohl, K. H., 1995. The composition of the continental crust: Geochimica et cosmochimica Acta, 59 (7): 1217-1232.

Wei, B., and Yang, L., 2010. A review of heavy metal contaminations in urban soils, urban road dusts and agricultural soils from China: Microchemical Journal, 94 (2): 99-107.

WHO, W. H. O., 2016. World health statistics 2016: monitoring health for the SDGs sustainable development goals, World Health Organization.

Xu, C., Qi, J., Yang, W., Chen, Y., Yang, C., He, Y., Wang, J., and Lin, A., 2019. Immobilization of heavy metals in vegetable-growing soils using nano zero-valent iron modified attapulgite clay: Science of the Total Environment, 686: 476-483.

Xu, N., Braida, W., Christodoulatos, C., and Chen, J., 2013. A review of molybdenum adsorption in soils/bed sediments: speciation, mechanism, and model applications: Soil and Sediment Contamination: An International Journal, 22 (8): 912-929.

Yakeem, A., and Onifade, T. O., 2012. Evaluation of some heavy metals in soils along major roads in Ogbomoso, South West Nigeria: Journal of Environment and Earth Science, 2 (8).

Zadnipryany, I., Tretiakova, O., Sataieva, T., and Zukow, W., 2017. Experimental review of cobalt induced cardiomyopathy: Russian Open Medical Journal, 6 (1): 103.

Zarasvandi, A., Rezaei, M., Sadeghi, M., Pourkaseb, H., and Sepahvand, M., 2018. Rare-earth element distribution and genesis of manganese ores associated with Tethyan ophiolites, Iran: A review: Mineralogical Magazine, 80 (1): 127-142. 